\title{
BREVE COMENTARIO A LA LEY 28/1998, DE 13 DE JULIO, DE VENTA A PLAZOS DE BIENES INMUEBLES ${ }^{1}$
}

\author{
CARMEN PASTOR ÁLVAREZ \\ Cartagena (Murcia), Noviembre de 1998
}

\begin{abstract}
SUMARIO: I. INTRODUCCIÓN. II. NOVEDADES MÁS IMPORTANTES DE LA NUEVA LEY DE VENTA A PLAZOS DE BIENES MUEBLES. III. EL ENTORNO NORMATIVO DE LA LEY DE VENTA A PLAZOS DE BIENES MUEBLES Y SU CONFIGURACIÓN JURÍDICA: 1.- La coexistencia normativa. 2.- ¿Carácter dispositivo o necesario de la LVPBM?. 3.- Ámbito de aplicación. 4.- Régimen jurídico aplicable: 4.1.- Forma y eficacia del contrato. 4.2.- Contenido «obligatorio» del contrato de venta. 4.3.- Claúsulas ineficaces. 4.4.- La facultad de desistimiento del comprador. 4.5.- El incumplimiento por el comprador. 4.6.Competencia y función judicial. 4.7.- La publicidad en el «precio» de los bienes objeto de esta Ley. 5.- El Registro de Venta a Plazos de Bienes Muebles y otras garantías. 5.1.- El Registro de Venta a Plazos de Bienes Muebles. 5.2.- Otras garantías: Especial referencia a la cláusula de reserva de dominio (pactum reservati dominii). 6.- El procedimiento a seguir en caso de incumplimiento del deudor.
\end{abstract}

\section{INTRODUCCIÓN}

La Ley 50/1965, de 17 de Julio, de Venta de Bienes Muebles a Plazos abordó en un momento crucial los problemas derivados de las ventas a plazos de bienes muebles como una modalidad de crédito que constituía un factor importante en los planes de desarrollo económico y cuya extensión era característica de la vida moderna. Con anterioridad a la misma las operaciones de esta especial naturaleza jurídica eran objeto de regulación por las normas generales del ordenamiento jurídico, pero la cambiante realidad social y económica reclamaba imperiosamente una regulación

1 Por María del Carmen Pastor Álvarez. Doctora en Derecho y Profesora del Departamento de Derecho Civil de la Universidad de Murcia. 
especial que estableciese los justos límites de facilidad y garantía para compradores y vendedores (Exposición de Motivos de la Ley de 1965).

Esta Ley era la respuesta jurídica a una realidad social y económica, cual era principalmente la demanda de los compradores o consumidores de adquirir y disfrutar determinados bienes en un momento determinado, cuando carecían de la liquidez necesaria para realizar tales adquisiciones mediante compras al contado. No obstante, también se intentó responder a las expectativas de los vendedores, centradas en las especiales garantías que la venta a plazos requería, así como de los terceros, estableciendo un sistema de publicidad igualmente adecuado a tal circunstancia ${ }^{2}$.

No hay duda pues que la finalidad esencial de la Ley de 1965 que lo es también en gran medida de la actual Ley 28/1998, de 13 de Julio, de Venta a Plazos de Bienes Muebles (en adelante LVPBM), que viene a sustituirla y que ahora es objeto de comentario, fue y es una finalidad política derivada de las circunstancias económicas y sociales que en su momento propiciaron su aparición y que aún hoy mantienen su actualidad, cual es corregir y paliar la desigualdad existente entre vendedor (normalmente grandes empresas) y comprador. Por este motivo las normas que priorizan la protección al comprador constituyen el eje alrededor del cual parece girar el resto de disposiciones normativas, que igualmente tienen esa finalidad proteccionista del consumidor en general. Es lo que se ha venido llamando legislación sobre el consumo y de protección al consumidor.

La Ley de 1965 así lo manifestaba, y la actual Ley de 1998 reafirma aun con mayor énfasis esta finalidad, cumpliendo de este modo una demanda normativa que igualmente se manifestaba en el Derecho europeo y en otras normas de Derecho interno, que tendremos ocasión de mencionar en estas líneas.

\section{NOVEDADES MÁS IMPORTANTES DE LA NUEVA LEY DE VENTA A PLAZOS DE BIENES MUEBLES}

La Exposición de Motivos de la nueva Ley 1998 se centra en dos grandes líneas para destacar las novedades más relevantes que se han introducido. Una, marcando las diferencias con la Ley anterior de $1965 \mathrm{y}$, otra, resaltando la necesaria armonización con la Ley 7/1995, de 23 de Marzo, de Crédito al Consumo; lo que fundamentalmente se resume en lo siguiente:

2 Para un mayor visión del entorno socio-económico de esta Ley vid. MARTÍNEZ DE AGUIRRE Y ALDAZ, C.: Las ventas a plazos de bienes muebles. Madrid 1988, págs. 149 y ss., así como la bibliografía en él citada. 
a) Con relación a la Ley 50/1965, de 17 de Julio, de Venta de Bienes Muebles a Plazos. Ésta ha quedado expresamente derogada con la nueva Ley (Disposición Derogatoria Única $1^{\circ}$ ) aunque de hecho parezca más una «modificación» que una «derogación» expresa. Se ha respetado, sin embargo y en gran medida, no sólo la denominacion de la Ley, en la que únicamente se ha trastocado el orden de los términos utilizados (Venta de Bienes Muebles a Plazos por el de Venta a Plazos de Bienes Muebles), sino incluso la estructura del texto -si bien la actual consta de tres Capítulos que como tales no existían con anterioridad, así como tampoco el título con que la actual enuncia el contenido de cada artículo para designar la materia a tratar- ${ }^{3}$ y la redacción del articulado con algunas variaciones: se ha reducido el número de preceptos ( 16 artículos, frente a los 24 de la Ley antigua) debido, por un lado, a la remisión que se ha hecho a la Ley de Crédito al Consumo de 1995 de todas aquellas cuestiones derivadas de la defensa del consumidor y, por otro lado, por el gran número de preceptos que han quedado vacíos de contenido por razones administrativas y de práctica económica por la aparición de nuevas formas de pago (arts. 12 o 22 , entre otros).

Se ha mantenido el ámbito de aplicación de la Ley (art. $1^{\circ}$ ), si bien con una nueva precisión: sólo los contratos que tengan por objeto bienes muebles «identificables» accederán al Registro previsto en la Ley y se beneficiarán de las garantías de su inscripción. Permanecen la definición de los contratos de préstamo de financiación, la facultad de desistimiento del comprador, el Registro de reservas de dominio y prohibiciones de disponer 4 , la competencia judicial y facultad moderadora de Jueces y Tribunales, y la ineficacia de los pactos, claúsulas y condiciones que se dirijan a eludir su cumplimiento.

3 La estructura concreta de la actual Ley, precedida de una Exposición de Motivos, parte de tres grandes Capítulos: Capítulo I «Definiciones y ámbito de aplicación», y los preceptos que comprende, del 1 al 5, recogen las siguientes materias: Ámbito de aplicación. Aplicación supletoria de la Ley, Definición del contrato de venta a plazos, Contratos de préstamo de financiación para las ventas a plazos, Exclusiones. Capítulo II «Régimen aplicable», comprende los arts. 6 a 14 y se refiere a: Forma y eficacia, Contenido del contrato, Penalización por omisión o expresión inexacta de claúsulas obligatorias, Facultad de desistimiento, Incumplimiento del comprador, Facultad moderadora de Jueces y Tribunales, Competencia Judicial, Publicidad y Claúsulas ineficaces. Capítulo III «Otras disposiciones», que recoge Ios arts. 15 y 16, relativos a: Registro de Venta a Plazos de Bienes Muebles e Incumplimiento del deudor. Además consta de tres Disposiciones Adicionales, relativas a: Arrendamiento financiero, Anotación preventiva de demanda y embargo, y Registro de Bienes Muebles; una Disposición Transitoria Única y tres Disposiciones Finales.

4 Manteniéndose casi a modo de excepción la normativa sobre dicho Registro (Orden de 15 de Noviembre de 1982, por la que se aprobó la Ordenanza para el Registro de Venta a Plazos de Bienes Muebles) «... en todo aquello que no se oponga a la presente Ley» (Disposición Derogatoria Única $3^{\mathrm{a}}$ de la LVPBM), pues ésta únicamente deja vigente la Ley de Crédito al Consumo, excepto su Disposición Final $2^{\mathrm{a}}$, y la citada Orden (Disposición Derogatoria Única $2^{\mathrm{a}}$ y $4^{\mathrm{a}}$ de la LVPBM). 
Se prevé asímismo la anotación preventiva de demanda y embargo, y la integración del Registro de Venta a Plazos de Bienes Muebles en el futuro Registro de Bienes Muebles, a la vez que se ha facilitado el procedimiento previsto para el cobro de los créditos nacidos de los contratos inscritos en el Registro a través de ciertos mecanismos (como fijar el tipo de la primera subasta en el precio de venta al contado si, a este efecto, las partes no han fijado otro en el contrato).

Por el contrario, se ha suprimido el desembolso inicial como condición necesaria para la perfección del contrato y se ha excluído expresamente el contrato de arrendamiento financiero en el objeto de la Ley, si bien se prevé la posibilidad de su inscripción (Disposición Adicional $1^{\mathrm{a}}$ ), pero haciendo constar su especial y propia naturaleza jurídica distinta de la compraventa a plazos.

b) Con relación a la Ley 7/1995, de 23 de Marzo, de Crédito al Consumo (en adelante LCC). La nueva Ley ha demostrado especial sensibilidad al intentar lograr la máxima coherencia entre sus normas y las de ésta, en tanto que sus preceptos afec$\tan$ y modulan el régimen de las ventas a plazos de bienes muebles. Existen por ello algunas coincidencias (por ejemplo, los arts. $7-7^{\circ}$ y $13-2^{\circ}$ de la LVPBM de idéntica redacción que el art. 17 de la LCC) y numerosas remisiones, ya mediante referencias expresas, ya trayendo a la Ley aquellas disposiciones que han sido declaradas de aplicación necesaria por estar dirigidas a la protección del consumidor ${ }^{5}$, como son básicamente las relativas a:

a) La tasa anual equivalente (art. $7-7^{\circ}$, y en la LCC los arts. $6-2^{\circ}$ a) y 18 ) y su modificación con arreglo a la LCC, la cual además establece en su Anexo una fórmula matemática para su cálculo basado en el coste total del crédito, y quedando expresado éste en un porcentaje anual sobre la cuantía concedida.

b) El régimen de penalizaciones que se prevé para para la omisión o expresión inexacta de claúsulas obligatorias (art. 8, y en la LCC el art. 7).

c) La publicidad relativa al precio de las cosas ofrecidas en venta a plazos (art. 13, y en la LCC el art. 17).

5 La protección al consumidor en la LCC se centra primordialmente en la publicidad, en la información que se le ha de proporcionar, en el contenido, la forma y los supuestos de nulidad de los contratos, y en la determinación de conceptos tales como el coste total del crédito y la tasa anual equivalente, que han de servir no sólo para informar mejor a los consumidores, sino también para dar mayor trascendencia al coste de los créditos y permitir el contraste entre las distintas ofertas (Exposición de Motivos de la LCC). 
d) Las deducciones a favor del vendedor o prestamista que, ante el incumpliento de las obligaciones del comprador, haya optado por resolver el contrato (art. 10, y en la LCC el art. 9).

\section{EL ENTORNO NORMATIVO DE LA LEY DE VENTA A PLAZOS DE BIENES MUEBLES Y SU CONFIGURACIÓN JURÍDICA}

\section{La coexistencia normativa}

La nueva LVPBM requiere una importante y obligada armonización con la abundante legislación que actualmente se dirige a la protección del consumidor, y en la que esta Ley incide en gran medida, sobre todo en lo que respecta a la LCC; determinando, en su caso, la aplicación preferente o supletoria, dispositiva o necesaria de sus normas.

El primer dato a tener en cuenta es el hecho de que la anterior Ley de 1965 de Venta de Bienes Muebles a Plazos ha quedado total y expresamente derogada y, en consecuencia, sustituida por la actual LVPBM (Disposición Derogatoria Única $1^{\text {a }}$ ) que, sin embargo, sí ha declarado expresamente vigente la Ley $7 / 1995$ de Crédito al Consumo (excepto su compleja Disposición Final 2a $2^{\mathrm{a}}$, objeto de derogación por la Disposición Derogatoria Única $2^{\mathrm{a}}$ de la LVPBM) mediante un sistema de remisión que la LVPBM ordena en todo aquello relacionado con las medidas dirigidas al incremento del nivel de «protección al consumidor», considerando incluso determinados preceptos como de aplicación imperativa o necesaria. Por ese motivo, el legislador de la nueva LVPBM más que en la citada protección -que no queda descuidada en absoluto- ha creído más oportuno concentrar su atención en el «contenido» del propio contrato de venta a plazos de bienes muebles, tal y como vamos a tener ocasión de comentar.

En este sentido, y ya en su momento, la Disposición Final $3^{\mathrm{a}}$ de la LCC previó la necesidad más o menos urgente de que se modificase la entonces y aún vigente Ley de 1965, con el fín de dotar a esta materia de una regulación legal uniforme; motivo por el cual se autorizó al Gobierno a desarrollar por medio de Real Decreto lo dispuesto en la presente Ley (LCC) en un plazo máximo de seis meses desde su publicación en el BOE. Las razones concretas de tal necesidad modificativa fueron esencialmente dos:

Primera, la coincidencia parcial o superposición del ámbito de aplicación de ambas leyes (Ley de 1965 y LCC), que requerían una armonización legal casi inmediata. 
Segunda, la peculiar caracterización de la actual legislación dirigida al incremento de la protección que se dispensa al consumidor de todo tipo de bienes y servicios. De hecho, la LCC tuvo por objeto incorporar al Derecho español la Directiva del Consejo de las Comunidades Europeas 87/102/CEE, de 22 de Diciembre de 1986, relativa a la aproximación de las disposiciones legales, reglamentarias y administrativas de los Estados miembros en materia de crédito al consumo, y su posterior modificación por la Directiva 90/88/CEE, de 22 de Febrero de 1990.

La reciente LVPBM se ha dictado, pues, para responder a estas exigencias iniciales, no sólo por imperativo de la LCC, sino para incrementar la base normativa existente dirigida a la adopción de mayores medidas de protección al consumidor. Respuesta que se produce fundamentalmente a través de dos vías: una, con disposiciones que obligan al concedente a informar, en los términos legalmente previstos, acerca de las características y condiciones del crédito al consumidor para la satisfacción de necesidades personales, así como a mantener su oferta durante un plazo determinado. Y otra, permitiendo al consumidor, previo cumplimiento de lo dispuesto en el art. 15 LCC, oponer las excepciones derivadas del contrato no sólo frente al empresario con el que hubiera contratado sino frente a otros empresarios a quienes aquél hubiera cedido sus derechos o que hubieran estado vinculados con él para financiar el contrato mediante la concesión de un crédito al consumidor.

Esta coexistencia de ambas normas se realiza en todo caso por imperativo legal, a través de un precepto que expresamente establece el sistema de aplicación «preferente» y «supletoria» de ambos cuerpos legales (art. 2 de la LVPBM); y en caso de yuxtaposición normativa de ambas leyes, la solución que arbitra el legislador se canaliza a través de dos vías:

a) Mediante la aplicación «preferente» de la LCC con relación a aquellos contratos sujetos a la LVPBM, siempre y cuando también sean objeto de inclusión en aquella Ley en todo lo que favorezca al consumidor, con la consiguiente aplicación supletoria de la LVPBM, en tales casos (art. 2 de la LVPBM).

b) Mediante la «incorporación» a los preceptos de la LVPBM del contenido de parte del articulado de la LCC. Buena muestra de ello, a título de ejemplo, son los arts. 6-2 a) y 13 que se corresponden con los arts. 18 y 17 de la LCC, respectivamente.

Pero es más, la actual LVPBM necesita armonizarse con otras normas legales de carácter interno y general, surgidas con anterioridad y posterioridad a la LCC y que igualmente tienen como finalidad el incremento de la protección del consumidor. Este es el caso de las siguientes leyes: 
a) La Ley 26/1984, de 19 de Julio, General para la Defensa de los Consumidores y Usuarios ${ }^{6}$ (en adelante LGDCU), cuyas normas en algunos aspectos concretos serán de aplicación a las ventas a plazos, en tanto que constituye una norma especial y de aplicación general dirigida a la defensa de consumidores y usuarios. En este caso, el comprador de los bienes sujetos a la LVPBM (y de los no sujetos a dicha ley, pero que realicen operaciones a plazo) no deja de ser un consumidor o usuario y, como tal, sujeto de la protección que le dispensa la LGDCU, siempre que el supuesto concreto quede incluido en el campo de aplicación de esta Ley (Cap. I), sus normas resulten más beneficiosas para el comprador-consumidor, y éste sea el destinatario final de los bienes y servicios (el art. $1-3^{\circ}$ de la LGDCU excluye, a efectos de la misma, del concepto de consumidor o usuario al que no sea destinatario final).

b) La reciente Ley $7 / 1998$, de 13 de Abril, sobre Condiciones Generales de la Contratación (en adelante LCGC) que modifica en su Disposición Adicional $1^{a}$ determinados preceptos de la LGDCU, con relación a las claúsulas abusivas en los contratos (arts. $2^{\circ}$, ap. 1 b) $10,23,34$ ) además de añadir la Disposición Adicional $1^{\mathrm{a}}$ y $2^{\mathrm{a}}$, mantiene un concepto amplio de consumidor, siguiendo el criterio de la Directiva que es objeto de transposición por la presente Ley, la Directiva 93/13/CEE, del Consejo, de 5 de Abril de 1993 sobre claúsulas abusivas en los contratos celebrados con consumidores, en virtud de la cual ha incluído no sólo las claúsulas abusivas extraídas en líneas generales de la Directiva, sino que ha añadido aquellas otras que, aún sin estar previstas en ella, se estima necesario que estén incluídas en el Derecho español por su carácter claramente abusivo. A ello se suma la pormenorizada regulación de las condiciones generales de la contratación, respecto de las que el legislador hace un especial énfasis en describir sus diferencias respecto de las cláusulas abusivas.

Siempre y cuando el caso concreto sometido a la LVPBM sea susceptible de ser incluído en el ámbito de aplicación de la Ley: el objetivo (art. 1), el subjetivo (art. 2) y el territorial (art. 3), y no sea uno de los contratos excluídos expresamente de la misma (art. 4), habrá que tener presente su más que evidente incidencia en las ventas a plazos de bienes muebles.

6 Antes de la vigencia de esta Ley no existía una regulación específica, ningún precepto concreto que tratase de condiciones generales, únicamente habían normas aisladas (Ley del contrato de Seguro, Ley cambiaria y del cheque, Ley General de la Publicidad, Ley de Defensa de la Competencia, etc). Se puede decir que con esta Ley se dió el primer paso para armonizar la incipiente protección al consumidor o usuario y las nuevas fórmulas contractuales nacidas ante las nuevas exigencias del mercado (contratación en masa), mención aparte del respaldo constitucional que la protección y defensa de los consumidores recibió expresamente en los arts. 51 y 53 de la Constitución de 1978. Precisamente en desarro1 lo de este mandato constitucional se promulgó la LGDCU, cuyo mérito más importante fue consagrar la defensa de consumidores y usuarios (art. 1-1 ${ }^{\circ}$ ) como principio general de nuestro ordenamiento jurídico. 
c) Ley 7/1996, de 15 de Enero, de Ordenación del Comercio Minorista (en adelante LOCM), que tiene por objeto regular determinadas ventas especiales y actividades de promoción personal. Si el pago en alguna de los tipos de ventas recogidos en esta Ley se realiza de forma aplazada también se verá afectada en la medida oportuna por la LVPBM en los términos que la misma señala.

Sin embargo, nuestro objetivo no pretende ser ambicioso en el sentido de conectar en profundidad toda la legislación vigente de protección al consumidor, de ahí que nos ceñiremos a comentar diferencias y similitudes de la presente LVPBM con la anterior Ley de 1965, a la que sustituye, y con la LCC, a la que expresamente se remite.

\section{2. ¿Carácter dispositivo o necesario de la LVPBM?}

En cuanto al carácter dispositivo o necesario de las normas que integran la LVPBM, podemos decir que ha sido una de las cuestiones más debatidas en la doctrina surgida a raíz de la Ley 50/1965. Y aún cuando han existido dos claras tendencias, una en defensa de su carácter dispositivo ${ }^{7}$, y otra, que propugnaba su carácter imperativo o necesario ${ }^{8}$, pensamos que actualmente lo más correcto y coherente es afirmar el carácter imperativo de la mayor parte de sus disposiciones («imperatividad limitada»), máxime a la vista de la numerosa normativa y preceptos concordantes que, tras la Ley de 1965, se han ido dictando en esta materia con el claro objetivo de proteger al consumidor, tratando de evitar que el principio de autonomía de la voluntad se convirtiera en la válvula de escape de vendedores y grandes empresas, cerrándoseles así la posibilidad de redactar cláusulas unilaterales que en mayor o menor medida pudieran contener situaciones desfavorables para el comprador-consumidor. Los argumentos en favor de esta postura son muy variados, pero tal vez el más significativo de todo ellos es el que resulta del mismo texto legal que hoy comentamos. La propia Exposición de Motivos de la LVPBM así lo expresa de forma indubitada al declarar que «...se ha incorporado el contenido de los artículos de la Ley de Crédito al Consumo que son de aplicación necesaria...», por lo que, como mínimo,

7 El mayor defensor de esta tendencia claramente minoritaria es BERCOVITZ: «Las ventas a plazos de bienes muebles», ADC/1966, págs. 117 y ss.; La claúsula de reserva de dominio. Madrid 1971; y en Comentarios a la Ley de Venta a Plazos de Bienes Muebles. Madrid 1977.

8 Esta tendencia es la predominante en nuestra doctrina y son partidarios de ella, entre otros, BALDO DEL CASTAÑO: Régimen jurídico de las ventas a plazos. Madrid 1974, págs. 28 y ss.; TORRES LANA, J.A.: «Notas críticas a la Ley de Venta a Plazos de Bienes Muebles», RDP/1975, págs. 604 y ss.; CABANILLAS SÁNCHEZ, A.: «El leasing financiero y la Ley de Venta a Plazos de Bienes Muebles», ADC/1980, págs. 765 y ss.; SOTO NIETO: Derecho vivo. Jurisprudencia comentada, vol. II. Madrid 1971; MARTÍNEZ DE AGUIRRE Y ALDAZ; C.: Las ventas a plazos de bienes muebles. Madrid 1988, págs. 27 y ss. 
los preceptos que de esta Ley se han incorporado directamente así como aquellos otros a los que se hace referencia expresa en la LVPBM gozan de dicho carácter imperativo. A ello se añadiría la principal finalidad que se persigue con la presente Ley (art. $1^{\circ}$ ), cual es la regulación de las adquisiciones a plazos y la protección del comprador-consumidor en ese ámbito.

\section{3. Ámbito de aplicación}

Tanto la Ley de 1965 como la actual han recogido de forma casi idéntica el ámbito de aplicación de esta norma, el cual además ha venido y viene determinado por un doble aspecto:

a) Un aspecto positivo, que determina expresamente aquello que es objeto de inclusión en la Ley (art. $1^{\circ}$ actual y antiguo art. $1^{\circ}$ ). Inclusión que se determina tanto en atención a un determinado tipo de bienes (bienes muebles corporales no consumibles e identificables) como en atención a un determinado tipo de relaciones jurídicas proyectadas en el contrato de compraventa a plazos y en el contrato de préstamo de financiación (a comprador y vendedor ${ }^{9}$ ), el cual además es objeto de inclusión en el art. 1 de la LCC que sujeta a su ámbito de aplicación dicho contrato ${ }^{10} \mathrm{y}$ siempre que los sujetos intervinientes en el mismo sean el empresario o concedente (art. 1-1 $1^{\circ}$ de la LCC), de un lado, y el consumidor (art. 1-2 $2^{\circ}$ de la LCC), de otro. Por último, también es objeto de inclusión en el art. $1^{\circ}$ de la LVPBM las garantías que se constituyan para asegurar el cumplimiento de las obligaciones nacidas de tales contratos (como son, a título de ejemplo, la determinación del tipo de la primera subasta en el precio de venta al contado si no se ha fijado otro en el contrato, o la fuerza ejecutiva de los contratos debidamente inscritos en el Registro).

Incidiendo con más detalle en este precepto, hay que destacar, primeramente, y en cuanto al tipo de bienes que pueden ser objeto de los contratos sometidos a esta Ley, que la redacción actual es prácticamente idéntica a la del art. 1 de la Ley de 1965 con la única salvedad de que no se mencionaba el adjetivo «identificables», en tanto que la actual Ley lo considera uno de los rasgos definitorios más importantes del objeto, máxime si tenemos en cuenta que el legislador ha estimado oportuno recoger su concepto en el párr. $2^{\circ}$ del art. $1^{\circ}$ del mismo texto legal: «A efectos de esta Ley se

9 Los dos tipos de financiación, a comprador y a vendedor (art. 4 de la LVPBM) ya aparecían en la ley de 1965, aunque se incorporaron de ese modo durante su tramitación parlamentaria, ya que en el Anteproyecto de la LCC tan sólo figuraba la financiación a vendedor; fue tras el debate de la Comsisión cuando se incluyó también en el texto definitivo el préstamo a comprador.

10 Aunque para la LCC lo realmente trascendente no es tanto la forma jurídica adoptada como la función económica que mediante ella se pretende conseguir, cual es la de financiar un acto de consumo (vid. ESTRADA ALONSO, E.: «El crédito civil al consumo en la Ley 7/1995, de 23 de Marzo», $\mathrm{CDC} / 1997, \mathrm{n}^{\circ} 22$, pág. 116). 
considerarán bienes identificables todos aquellos en los que conste la marca y número de serie o fabricación de forma indeleble o inseparable en una o varias de sus partes fundamentales, o que tengan alguna característica distintiva que excluya razonablemente su confusión con otros bienes». La Ley anterior no incorporaba tal definición en su propio texto, aunque sí lo hizo a través de la normativa complementaria ${ }^{11}$.

A sensu contrario todos aquellos bienes, aunque sean muebles y corporales no consumibles que no puedan ser identificables quedarían excluídos del ámbito de la Ley y, por consiguiente, también excluídos de la inscripción en el Registro de Venta a Plazos de Bienes Muebles. Añadir que quedamos a la espera, según preceptúa la Disposición Final Única de la Ley, de que «El Gobierno, a propuesta conjunta de los Ministros de Justicia y de Economía y Hacienda, dictará las disposiciones necesarias para el desarrollo y aplicación de esta Ley».

Y, segundo, el art. 1 recoge qué tipo de relaciones jurídicas son objeto de la presente Ley, para posteriormente en los arts. 3 y 4 proceder a su definición. Hablamos de los contratos de venta a plazos o contrato de adquisición y del de préstamo de financiación, coincidentes en gran medida con la regulación que de los mismos se contenía en el anterior art. 2 de la Ley de 1965. Pero, veámos las variaciones más relevantes introducidas por la actual normativa:

Una primera cuestión a destacar en este tipo especial de compraventa es su caracterización no sólo como una compraventa de carácter civil 12 sino sobre todo su cata-

11 La Ley de 1965 no desconocía este rasgo a la hora de definir el objeto de la misma, si observamos su inclusión y su definición en una norma complementaria de las muchas que se dictaron con este carácter. Hablamos del Decreto 1193/1966, de 12 de Mayo (así como de la Orden de 15 de Noviembre de 1982, en su art. 7), cuyo art. 2 exigía como uno de los requisitos para que tales bienes quedaran sometidos a la Ley de 1965, que fueran «identificables», realizando a tal efecto una definición muy similar a la contenida en el $1-2^{\circ}$ de la actual Ley: «Se considerarán bienes identificables, a efectos del Registro de reservas de dominio y prohibiciones de disponer, todos aquellos en los que conste la marca y número de serie o fabricación de forma indeleble o inseparable, en una o varias de sus partes fundamentales». Decreto que, por otro lado, ha sido objeto de derogación expresa en la Ley actual, en la Disposición Derogatoria Única $3^{\mathrm{a}}$, acabando definitivamente con algunas divergencias que suscitaba la diferente redacción de la Ley de 1965 y del Decreto de 1966, sobre todo en el punto relativo a la «identificabilidad» del objeto (pues en dichos textos parecía distinguirse entre identificabilidad general, a efectos de la aplicación de la Ley, e identificabilidad registral, a efectos de su inscripción en el Registro).

12 La atribución del carácter civil o mercantil a este tipo de compraventa ha sido un tema muy controvertido en nuestra doctrina, sin embargo, parece que resulta predominante la postura que preconiza su naturaleza civil (TORRES LANA, BERCOVITZ, VÁZQUEZ RICHART, MARTÍNEZ DE AGUIRRE...) frente a los que difienden su naturaleza mercantil (BALDO DEL CASTAÑO, ALBALADEJO...), máxime si tenemos en cuenta la expresa exclusión del art. 5-1 ${ }^{\circ}$ en clara referencia a las compraventas 
logación como contrato real ${ }^{13}$, alejándose así de la normativa general de la compraventa regulada en el Código Civil que la considera de carácter consensual, como es sabido. Y ello, porque la perfección del tipo de contrato que nos ocupa está condicionada a la entrega de la cosa objeto del contrato (sin que entremos a considerar el tipo de entrega ${ }^{14}$ ); constituyendo una cuestión muy debatida en la doctrina que se ocupó del tema a raíz de la Ley de 1965. Debate que aún hoy mantiene su actualidad, y a él nos remitimos, sobre todo si tenemos presente que la Ley de 1998 sigue configurando con caracter real la venta a plazos de bienes muebles, precisamente porque se mantiene, al menos, la exigencia de la entrega de la cosa para la perfección del mismo ${ }^{15}$.

mercantiles, y que se mantiene en los mismo términos que la anterior legislación, por lo que la discusión doctrinal en esta cuestión sigue conservando su actualidad, y a ella remitimos todas las consideraciones que este tema conlleva.

13 Los contratos reales han sido calificados doctrinalmente como excepción al principio de perfección consensual del contrato, al supeditar a la entrega de la cosa el nacimiento o existencia de éste. En la doctrina española han mantenido el carácter real de estos contratos, entre otros, DE COSSÍO: «La Ley de Ventas a Plazos», RCDI/1965 (XLI), págs. 1126 y ss.; CABANILLAS, P.: «Discurso...», cit., pág. 1145; BERCOVITZ: «Las ventas...», cit., pág. 134; SOTO NIETO: Derecho vivo..., cit., pág. 523; TORRES LANA: «Notas críticas...», cit., pág. 613. Sin embargo, quien más ha cuestionado la existencia como categoría de los contratos reales ha sido JORDANO BAREA: La categoría de los contratos reales. Barcelona 1958, págs. 140 y ss., y su conocida tesis de que, en nuestro Derecho, la entrega de la cosa puede quedar fuera del proceso formativo del contrato, admitiendo la configuración consensual de estos contratos. ROCA GUILLAMÓN, J.: Comentarios al Código Civil y Compilaciones Forales (Dir. ALBALADEJO), T. XVII, vol. $1^{\circ}$-A (art. 1258 del CC). Edersa, Madrid 1993, pág. 437, que más recientemente también ha abordado esta cuestión, resume el problema en los siguientes términos: «...una vez prefeccionado el contrato, éste será existente y válido, aunque no plenamente eficaz, en tanto no se cumpla el requisito de la datio rei. Pero es que precisamente por ser parcialmente eficaz obliga a las consecuencias que derivan de su naturaleza y que sean conformes a la buena fé, al uso o a la ley, según el art. 1258, consecuencias entre las que cabe incluir la obligación de establecer los presupuestos que la ley exige para la eficacia del contrato que tanto puede consistir en la datio rei como en la predisposición por la otra parte para recibir la cosa». Vid. también ATAZ LÓPEZ, J. en estos mismos Comentarios, pág. 42 que también se refiere a este tema en conexión con el art. 1254 del CC.

14 Según DÍEZ-PICAZO Y GULLÓN: Sistema de Derecho Civil, T.II. Madrid 1983, pág. 381, la entrega de la cosa no tiene que ser sólo la real o material, pues la Ley no deroga las formas espiritualizadas de entrega o traditio. Para BERCOVITZ: Comentarios a la Ley..., cit., pág. 204, en cambio, ha de tratarse de una entrega real, debiendo quedar eliminadas las diversas formas de tradición fingida o documental; de la misma opinión MARTÍNEZ DE AGUIRRE: Las ventas..., cit., págs. 66-67, para quien esta Ley lo que pretende es la entrega real o material de la cosa, es decir, la entrega en el sentido del art. 1462$1^{\circ} \mathrm{del} \mathrm{CC}$, de forma que las formas más o menos espiritualizadas que establece el CC no supondrán entrega a efectos de dicha Ley.

15 Aunque el actual art. 3 ya no exija el desembolso inicial para la perfección del contrato, ello no implica que el mismo haya perdido su naturaleza real. Sigue siendo un contrato con un predominio de su naturaleza real, si tenemos presente que dicho carácter real se deriva precisamente de la entrega de la cosa, única prestación cuya consecuencia exige la Ley para el perfeccionamiento de la venta. Podríamos decir, en todo caso, que se trataría de un contrato de naturaleza mixta: por una lado, real en cuanto a la entrega por el vendedor de la cosa vendida; afirmación que viene apoyada por la redacción del propio art. 3 de 
El contrato de venta a plazos se define en el actual art. 3 introduciendo una de las más importantes novedades respecto a la anterior regulación: la relativa al pago del precio. El precepto dice que el pago del precio se realizará «...de forma total o parcialmente aplazada en tiempo superior a tres meses desde la perfección del mismo». Es decir, mientras que la Ley de 1965 exigía del comprador, en el «mismo momento de la entrega» de la cosa por el vendedor una «parte del precio», el llamado «desembolso inicial» como requisito de perfección del contrato, la actual normativa no lo exige bajo esta caracterización, sin que por ello esta figura haya dejado de regularse u omitirse por la actual ley. El desembolso inicial sigue siendo posible, si bien ya no condiciona la propia perfección del contrato. Su vigencia dependerá de que haya sido o no pactado expresamente por las partes (art. $7-4^{\circ}$ ) y, en tal caso, sin la función que anteriormente cumplía en la perfección del contrato.

Otra variación en el actual contrato de venta a plazos se sitúa en el señalamiento de los períodos de aplazamientos de los pagos. En este sentido existe una coincidencia sólo parcial respecto de la ley anterior. Ambas normas coinciden en señalar el aplazamiento mínimo de tres meses, pero no presentan tal coincidencia en cuanto al aplazamiento máximo. La Ley anterior marcaba con carácter imperativo tal período máximo mediante remisión al art. 20 de la misma Ley (que concedía tal facultad al Gobierno); la actual Ley, por el contrario, omite toda referencia al respecto, por lo que debemos deducir que no ha sido voluntad del legislador la de establecer períodos máximos, dejando tal extremo a la voluntad de las partes. Para la nueva normativa lo realmente importante es señalar el tiempo mínimo de tres meses, haciendo abstracción del plazo máximo e incluso del número de pagos aplazados. Estas afirmaciones se ven reforzadas no sólo por el propio art. 3 sino inclusive por el art. 4 apartados b) y c), referidos al contrato de financiación. En concreto el apartado c) expresa fielmente esta afirmación: «...quedando obligado el comprador a devolver el importe del préstamo en uno o varios plazos superiores a tres meses». Este aspecto se complementa con el art. 2 b) de la LCC que prohibe, por un lado, el pago en un único plazo si éste se realiza en un tiempo inferior a tres meses y, por otro lado, el reembolso del crédito en cuatro plazos, como máximo, en un período de tiempo no superior a los doce meses.

la Ley «...una de las partes entrega a la otra...», en comparación con el art. 1445 del CC. regulador de la compraventa en general «.... uno de los contratantes se obliga a entregar...». Y, de otro lado, sería consensual en cuanto al pago de los plazos por el comprador, los cuales no precisan realizarse en el mismo momento de la entrega para que el contrato quede perfeccionado (vid. en este sentido la doctrina anterior a la nueva Ley, entre otros, BALDO DEL CASTAÑO: Régimen jurídico..., cit., págs. 63 y ss.; MARTÍNEZ DE AGUIRRE: Las ventas a plazos..., cit., pág. 64, para quienes, a pesar de la exigencia del desembolso inicial para la perfección del contrato, entendían que dicha entrega no afectaba negativamente a la perfección del contrato). 
Con relación al préstamo de financiación -cuya «cierta dependencia» del contrato de compraventa no ofrece ningún genero de dudas ${ }^{16}$ - tanto la Ley anterior (art. 3) como la actual (art. 4) regulan las dos modalidades que puede revestir este contrato: el préstamo de financiación a vendedor, por un lado, y el de financiación a comprador, por otro, máxime si tenemos presente que las ventas a plazos son vehículos de crédito y la financiación se configura como pieza esencial en estas compraventas. La redacción de ambas modalidades es muy similar, únicamente que la ley actual ha cuidado más el aspecto sistemático separando claramente ambos supuestos en sus tres párrafos, a la vez que mejora las expresiones utilizadas.

Las novedades más destacables que se han producido han sido a propósito del préstamo de financiación a comprador ${ }^{17}$. En este sentido, la redacción del actual art. 4- $3^{\circ}$ contiene algunas variaciones destacables con relación al anterior art. 3-2 ${ }^{\circ}$ : primero, se permite que el tercero pueda facilitar al comprador, como máximo, el «coste de adquisición del bien», mientras que anteriormente la aportación máxima del tercero se reducía al «importe aplazado del precio», no pudiendo cubrir con su financiación el coste total del bien; lógica consecuencia, en cierto modo, de la obligación que asumía el comprador de realizar el desembolso inicial para lograr la perfección del contrato. Y, segundo, para la devolución del importe del préstamo se ha fijado un plazo mínimo (uno o varios plazos superiores a tres meses), pero no el máximo, cuando la normativa anterior sí lo fijaba (art. 20). Esta cuestión queda además afectada por la remisión expresa del art. $3-2^{\circ}$ a la LCC, la cual excluye de su ámbito de aplicación a aquellos contratos que impongan unos determinados plazos, y que su art. 2 b) concreta.

Al hilo de estas observaciones nos surge la siguiente interrogante: ¿el importe del préstamo ha de destinarse, en todo caso, a pagar el precio del bien comprado a plazos?. Parece que si la Ley regula expresamente este tipo especial de préstamo es porque su «destino» se halla fijado de antemano a la adquisición del bien objeto de la venta a plazos 18; en caso contrario, si el prestatario o comprador pudiese destinarlo

16 Vid. al respeto la STS de 17 de Junio de 1970, que constituyó la afirmación más clara en este sentido al declarar la ineficacia de las garantías inscritas a favor del financiador si la venta no se perfeccionó por falta de entrega de la cosa; así como las distintas teorías que califican esa relación de interdependencia contractual en TORRES LANA: «Notas críticas...», cit., págs. 625 y ss.

17 En el supuesto de financiación a vendedor no se ha introducido novedades destacables y, en principio, tampoco surgen problemas de relevancia, recogiéndose en términos idénticos tanto por la Ley anterior como por la actual las dos formas que se admiten de este supuesto: mediante cesión o subrogación del crédito del vendedor al financiador, o bien mediante concierto conjunto de ambos en proporcionar la adquisición al comprador.

18 La actual Ley así lo entiende en la literalidad que se deriva del concepto de préstamo de financiación del art. 4-1 $1^{\circ}$ : «Los préstamos destinados a facilitar la adquisición, a los que se refiere el art. 1 ...». Y del párrafo $3^{\circ}:$ «...aquellos configurados por vendedor y comprador, determinantes de la venta sujeta a esta Ley...» 
a otra finalidad, estaríamos ante un préstamo normal regido por las normas generales del Código Civil, relativas al contrato de préstamo (arts. 1740 y ss.). La exigencia de ese destino específico se podría incluso configurar como una obligación del comprador derivada de su propia naturaleza o específica finalidad financiadora, tanto si se pacta expresamente, asumiendo la forma de condición resolutoria expresa, como si no; y seguirá siéndolo también por constituir una obligación derivada de la propia esencia del contrato de préstamo de financiación ${ }^{19}$.

b) Un aspecto negativo, que provoca la exclusión expresa de determinados supuestos (art. $5^{\circ}$ de la Ley de 1998 y $4^{\circ}$ de la Ley anterior). Lo más destacable es que se introduce como novedad la exclusión del ámbito de la Ley de los contratos de arrendamiento financiero, que bajo la Ley de 1965 no se excluían. No obstante, la Ley prevé expresamente su inscripción haciendo constar su especial y propia naturaleza jurídica (DA primera), que declara distinta de la compraventa a plazos.

Por lo demás, tanto la redacción anterior como la actual también son similares: los párrafos $1^{\circ}$ y $2^{\circ}$ son idénticos (el párr. $1^{\circ}$ sigue excluyendo las compraventas mercantiles, y el párr. $2^{\circ}$ sigue exigiendo la confluencia de los factores de la ocasionalidad y la falta de finalidad de lucro para que opere la exclusión de la venta y del préstamo de esta Ley). Los párrafos $3^{\circ}$ y $4^{\circ}$ han cambiado únicamente el orden numérico, aunque el $3^{\circ}$ ahora es más preciso al incluir ademas de los préstamos a las ventas; y el actual párr. $4^{\circ}$ remite a la determinación reglamentaria la fijación de la cuantía inferior, con el fín de excluir los contratos de venta a plazos o préstamos de financiación que no superen dicha cuantía (cuando anteriormente se dejaba su determinación expresa al Gobierno, completándose con el art. 20, que concedía a éste además, otras facultades).

En resumen, las diferencias más relevantes se reducen fundamentalmente a dos: 1) la nueva Ley se abstiene de mencionar qué ocurre con las operaciones de comercio exterior, que anteriormente se excluían expresamente del ámbito de aplicación de la Ley (art- $4-5^{\circ}$ ); de donde podemos inferir que sí podrían quedar incluídas si se adaptan a las exigencias de la presente Ley, bajo la amplitud que permite el art. $3-2^{\circ}$, y porque si el legislador las hubiese querido excluir expresamente habría mantenido la redacción anterior como ha hecho con los apartados mencionados. Y, 2) la nueva Ley excluye de forma novedosa el arrendamiento financiero, cuando la ley anterior no contenía referencia alguna en este sentido; siendo de destacar la regulación que del mismo se realiza en la DA primera, a efectos de inscripción, haciendo constar su especial y propia naturaleza jurídica (distinción que anteriormente ya se venía estableciendo, aunque se carecía del apoyo legal actual).

19 Cfr. TORRES LANA: «Notas críticas...», cit., págs. 622-623. BERCOVITZ: Las ventas a plazos..., cit., págs 163-164, por el contrario, no incluye esta obligación de invertir el importe del préstamo en el bien comprado a plazos entre las obligaciones del comprador. 
Este sistema de exclusiones queda afectado por la LCC, que en su art. $2^{\circ}$ recoge los supuestos que no quedan amparados por su normativa y que por tanto se excluyen de su ámbito de aplicación ${ }^{20}$. Ello implica que las venta a plazos de bienes muebles queda afectada por un doble sistema de exclusiones: el art. $5^{\circ}$ de la Ley de 1998 y el art. $2^{\circ}$ de la LCC; consecuencia del carácter imperativo que la LCC posee en virtud de la afirmación que a tal efecto contiene el art. 2 de la LVPBM

\section{Régimen jurídico aplicable}

\subsection{Forma y eficacia del contrato}

$\mathrm{Al}$ igual que ocurría con su antecesora, la reciente LVPBM condiciona la validez de los contratos ${ }^{21}$ sometidos a ella al requisito de la forma escrita (art. 6- $1^{\circ}$ y antiguo art. 5, asímismo el art. 6-1 $1^{\circ}$ de la LCC en idénticos términos, y de forma similar el art. $5-1^{\circ}$ de la LCGC ${ }^{22}$ ), constituyéndose como contratos formales ${ }^{23} \mathrm{y}$, a nuestro

20 El ámbito de exclusión de determinados supuestos de la LCC han sido clasificados doctrinalmente en cuatro grupos: límites objetivos (art. 1-3 $3^{\circ}$, cuantitativos (art. 2-1 ${ }^{\circ}$ a), temporales (art. $2-1^{\circ}$ b) y funcionales (art. 2-1 c) y d), sin que en ningún caso sean coincidentes con los de la LVPBM.

21 Sin ánimo de pormenorizar en la interrelación de cuestiones tan importantes y debatidas del Derecho de obligaciones y contratos como son las relativas a forma, validez, eficacia o perfección de los contratos, creemos oportuno incidir muy brevemente en la interpretación de algunas de las nociones y expresiones a que la redacción del Cap. II de la Ley pudiera dar lugar.

El párr. $1^{\circ}$ del art. 6 de la Ley actual determina claramente el carácter formal de estos contratos y condiciona la validez de los mismos a la forma escrita. Si nos trasladamos a la regulación general contenida en CC, observamos como su art. 1258 presupone la existencia y perfección misma del contrato mediante la prestación del consentimiento; sin embargo, la perfección no supone en manera alguna que el contrato formado sea válido y eficaz, sino sólo que ha alcanzado existencia como acto jurídico negocial. En este caso concreto, el contrato existe, pero sino se respeta la forma carecerá de validez. La perfección es, pues determinante del momento inicial de la existencia del contrato y, por tanto, normalmente, también de su eficacia.

La perfección es, como dice LALAGUNA DOMÍNGUEZ, E.: «Sobre la perfección de los contratos y el Código Civil», en Hom. a J. ROCA. Univ. de Murcia 1989, págs. 1071 y ss., presupuesto de validez y de eficacia contractual, pero no determinante de ésta. En realidad, la perfección del contrato determina el comienzo posible y normal de los efectos del contrato, pero la eficacia, expresada en la generación de obligaciones dimanantes del mismo se hace depender de que concurran las condiciones necesarias para su validez (vid. también en este sentido ROCA GUILLAMÓN: Comentarios al Código Civil... (art. 1258), cit., págs. 420 y ss.).

22 Excepcionalmente al régimen establecido en estas normas, que no lo es respecto del régimen general de libertad de forma recogido por el CC en el art. 1278, el art. 11 de la LOCM se decanta por la libertad de forma, si bien supeditada a «...su expresa sumisión a lo señalado en el CC, en el CCom., y en esta o en otras leyes especiales». Entre éstas se encontraría la LVPBM, que impone la formalización de sus contratos, y ésta sería la fórmula aplicable dada la especialidad de la Ley y la salvedad que realiza la propia LOCM.

23 Como dice ROCA GUILLAMÓN: Comentarios al Código..., cit., págs. 420 y ss., «...el principio de que los contratos se perfeccionan por el mero consentimiento encuentran su excepción en los 
modo de ver, en un doble aspecto: uno, en el sentido de que la forma escrita se añade al consentimiento, objeto y causa (art. 1261 del Código Civil) como elemento esencial de los mismos 24; y otro, ante la exigencia legal de que tal formalización se realice de una manera determinada: «Se formalizará en tantos ejemplares como partes intervengan, entregándose a cada una de ellas su correspondiente ejemplar debidamente firmado». (frase ésta última que constituye, a efectos de redacción, la única diferencia con su correlativo art. 5 de la Ley anterior), proporcionándose de este modo una completa información del contenido del contrato a cada uno de los intervinientes en el mismo.

Aunque el art. 6 de la LVPBM no establece expresamente la sanción aplicable ante la falta de las mencionadas formalidades (lo que sí hace respecto de otras omisiones), creemos oportuno recurrir al art. $7-1^{\circ}$ de la LCC que sí sanciona explícitamente la falta de forma con la nulidad 25 .

Tal consideración como contrato formal, no obstante, parece perder su inicial aseveración si observamos lo dispuesto en el art. 3-2 $2^{\circ}$ de la Ley (antiguo art. 2-2 $2^{\circ}$ de forma casi idéntica) cuando expresa que: «También se entenderán comprendidos en esta ley los actos o contratos, cualquiera que sea su forma jurídica o la denominación que las partes le asignen, mediante las cuales las partes se propongan conseguir los mismos fines económicos que con la venta a plazos». De este precepto, la primera idea que nos surgiría sería afirmar el expreso reconocimiento del principio de libertad de forma (art. 1278 del Código Civil) al utilizar la expresión «cualquiera

supuestos de datio rei y cumplimiento del requisito de forma ad solemnitatem». Afirmación que se cumple sin duda en este tipo de contratos, y a la vista están los arts. 3 y 6 de la LVPBM.

24 Bajo la Ley anterior se inclinaban por el carácter esencial de la forma la doctrina mayoritaria (vid. DE COSSÍO: «La ley...», cit., pág. 1129; BERCOVITZ: «Las ventas...», cit., págs. 148-149; TORRES LANA: «Notas críticas...», cit., pág. 612. En concreto MARTÍNEZ DE AGUIRRE: Las ventas..., cit., pág. 69, que resume las diversas fundamentaciones que conducen a dicha posición: por lo tajante de la expresión utilizada en el art. 5, por el carácter imperativo de la Ley, y por las finalidades perseguidas en el art. 6). Por el contrario, BALDO DEL CASTAÑO: Régimen jurídico..., cit., págs. 50 y ss., disentía de esa opinión mayoritaria, en el sentido de de entender que sólo un análisis superficial del tema conduciría a afirmar que al venta a plazos es un contrato formal.

25 Sanción que ha sido criticada por su dureza por algún sector doctrinal, así como por los perjuicios que puede ocasionar al consumidor (art. 1303 del CC), proponiendo como solución la adoptada por el Derecho alemán que establece, en principio, la nulidad del contrato que no conste por escrito excepto en el caso de que el dinero hubiese sido entregado al consumidor. En tal caso, el contrato sería válido y podría completarse con el derecho del consumidor de exigir, conforme a los arts. 1279 y 1280 del CC, la correspondiente documentación por escrito (vid. ROCA GUILLAMÓN, J.: «Los contratos de crédito al consumo. Forma y contenido, reembolso anticipado y cobros indebidos (Ley 7/1995, de 23 de Marzo)», en Crédito al Consumo..., pág. 155, ALFARO AGUILA-REAL, J.: «Observaciones..., pág. 1042; ANDREU MARTÍ, M.M.: El cliente bancario, pág. 160). 
que sea su forma»; sin embargo, -y con respeto en todo caso a las normas anteriores de carácter imperativo, pues, afirmar lo contrario carecería de sentido alguno-creemos que no debiera entenderse en este sentido sino que, al amparo del principio de libertad de contratación, las partes pueden utilizar otras figuras contractuales para los mismos fines.

El resto de apartados del art. 6 de la LVPBM, que coinciden literalmente con el art. $14-1^{\circ}$ de la LCC, se refieren a la eficacia del contrato de venta ${ }^{26}$ cuando exista vinculación entre el contrato de venta (o adquisición) y el de obtención de un crédito de financiación, haciéndose depender la eficacia del propio contrato o la eficacia de ciertas cláusulas, del cumplimiento de determinadas circunstancias. Tales circunstancias son las siguientes:

a) La eficacia general del contrato de venta se hará depender de la efectiva concesión del crédito (art. 6-2 ${ }^{\circ}$.

b) Si alguna cláusula o pacto obliga al comprador a un pago al contado o a otras fórmulas de pago si no se obtiene el crédito de financiación previsto (art. 6-3 ${ }^{\circ}$, ap. $1^{\circ}$ ), se producirá la nulidad de las mismas.

c) Si en alguna de las cláusulas del contrato el vendedor exigiese que el crédito de financiación únicamente fuese otorgado por un determinado concedente, ésta se tendría por no puesta (art. 6-3, ap. $2^{\circ}$ ).

El art. 14, párr. $2^{\circ}$ de la LCC amplia y matiza los supuestos anteriores, extendiendo la ineficacia del contrato de venta al contrato de financiación cuando concurran las circunstancias previstss en los párrafos a), b) y c) del art. $15-1^{\circ}$ de la LCC, en cuyo caso se producirán los efectos previstos en el art. 9 de la misma Ley (estableciendo un detallado sistema de liquidaciones, que se aplicará igualmente cuando cuando proceda la resolución del contrato de adquisición). Y, finalmente, el párr. $3^{\circ}$ del mismo precepto exige que conste de forma obligatoria, mediante documento, la acreditación de la identidad del proveedor de los bienes o servicios objeto del con-

$26 \mathrm{Al}$ igual que hemos hecho en la nota anterior respecto de la forma, la eficacia del contrato a la que se alude directamente en la Ley, en sus párrafos $2^{\circ}$ y $3^{\circ}$ (art. 6), también debe ser objeto de matización. En principio, el consentimiento actúa como factor desencadenante de la eficacia del contrato, sin embargo, esa dualidad consentimiento (perfección)-eficacia no siempre es cierta, puesto que ésta última no siempre se sigue de manera inmediata del hecho de la perfección, ya que una vez perfeccionado el contrato, el comienzo de la produción de efectos puede quedar supeditado al cumplimiento de determinados presupuestos previos, en función de la propia voluntad de las partes o de una exigencia legal. Tal es el caso del párr. $2^{\circ}$, que subordina la producción de dichos efectos a una condición: la obtención del crédito de financiación (vid. sobre este tema LALAGUNA: «Sobre la perfección...», cit., págs. 1071 y ss.). 
trato de consumo y la del concedente del contrato de crédito, de forma que cada uno de ellos aparezca ante el consumidor como sujeto de las operaciones relacionadas con los respectivos contratos de los que es parte (sin perjuicio de lo establecido en el art. 15 LCC). Por otro lado, al consumidor, en el precepto in fine, se le concede la opción de no concertar el contrato de crédito realizando el pago en la forma que acuerde con el proveedor del contrato de consumo.

En definitiva, el art. 6 párrafos $2^{\circ}$ y $3^{\circ}$ de la LVPBM ha de concectarse, en todo caso, con los preceptos mencionados de la LCC, siempre que exista una vinculación entre el contrato de adquisición de bienes o servicios y el contrato de financiación de los mismos. Es decir:

a) Se condiciona la eficacia del contrato de venta a plazos a la obtención del crédito de financiación, cuando se establezca expresamente que tal operación incluya la obtención de dicho crédito. Se sancionará con la nulidad el pacto por el cual se obligue al comprador al pago al contado a otras fórmulas de pago, para el supuesto de que no se obtenga el crédito de financiación previsto (arts. $6-2^{\circ}$ y $3^{\circ}$ de la LVPBM y $14-1^{\circ}$ de la LCC).

b) Como consecuencia de tal vinculación el art. 15 de la LCC permite al comprador o adquirente el ejercicio de los derechos que le correspondan tanto frente al proveedor de los bienes y servicios adquiridos mediante el contrato de crédito como frente al empresario que hubiera concedido el crédito, siempre que concurran «todos» los requisitos que el citado precepto prevé. Solución legislativa en favor del compradorconsumidor que se justifica plenamente por la aparente debilidad de éste frente a la otra parte de la relación jurídica, en principio más fuerte por estar integrada por el proveedor de los bienes o servicios y el empresario concedente del crédito.

\section{2.- Contenido «obligatorio» del contrato de venta}

El contenido de un contrato es todo el entramado de decisiones adoptadas por las partes que establecen las reglas de conducta y la regulación de los intereses adecuado a las necesidades y deseos de las partes, y que éstas amparan y confirman ${ }^{27}$; o como decía el profesor DE CASTRO ${ }^{28}$, la «médula» del contrato.

Por ello, quizás, el art. 7 de la LVPBM se ha querido referir expresamente a esta cuestión, si bien con la peculiaridad de combinar el aspecto dispositivo, propio y

27 En estos términos REVERTE NAVARRO, A.: Comentarios al Código Civil y Compilaciones forales (Dir. ALBALADEJO), T.XVII, vol 1 ${ }^{\circ}$-A (art. 1255), págs. 100 y ss.

28 Cfr. DE CASTRO, F.: El negocio jurídico. Madrid 1963, págs. 31-32. 
característico de nuestro sistema contractual, con el aspecto imperativo que se refleja en una enumeración de «circunstancias» (en palabras del propio texto) que con carácter obligatorio se ha de contener en los contratos sujetos a esta Ley.

El primero, el aspecto dispositivo resulta del principio general recogido en el art. 1255 del CC y que en materia de contratos rige en nuestro ordenamiento jurídico, es decir, el principio de libertad contractual o autonomía de la voluntad; pues como dice ALBALADEJO 29 con relación a esta terminología: «la noción de autonomía privada incluye, como una de sus manifestaciones más genuina, la libertad contractual. La noción, más específica, de libertad contractual presupone la de autonomía privada» 30 . De hecho, la redacción del art. 1255 coincide en parte con la del art. 7 de la Ley $a b$ initio (cuando utiliza la frase «Los contratos sometidos a la presente Ley, además de los pactos y claúsulas que las partes libremente estipulen...»), lo cual aleja toda interpretación en otro sentido.

Sin embargo, no podemos dejar de mencionar una circunstancia que también habremos de tener presente y que viene a ensombrecer el aludido carácter dispositivo del contenido del contrato, cual es el hecho de que tales pactos y claúsulas, en virtud sobre todo de los sujetos que intervienen (vendedores-empresas y compradoresconsumidores-usuarios), se engloban dentro de las llamadas «claúsulas o condiciones generales de la contratación» ${ }^{31}$. Claúsulas que, hasta hace bien poco, implicaban su sometimiento a la LGDCU, y cuyo art. 10-2 ${ }^{\circ}$ definía (de modo también muy semejante al art. 1255 del Código Civil) de la siguiente manera: «A los efectos de esta Ley, se entiende por claúsula, condiciones o estipulaciones de carácter general, el conjunto de las redactadas previa y unilateralmente por una empresa a grupo de empresas para aplicarlas a todos los contratos que aquella o ésta celebren, y cuya aplica-

29 Cfr. ALBALADEJO, M.: Derecho Civil, II-1. Barcelona 1989, pág. 391.

30 Veáse para un estudio detallado de este tema, así como la bibliografía más relevante, en REVERTE NAVARRO: Comentarios al Código..., cit., págs. 100 y ss.

31 Según afirma REVERTE NAVARRO: Comentarios al Código..., cit., págs. 162 y ss., la intervención de consumidores y usuarios, como es el caso, hace que hablemos de un «contenido predispuesto» (arts. $55-1^{\circ}$ y $53-3^{\circ}$ de la Constitución), es decir, de condiciones generales de la contratación; ello hace que se genere una peculiar relación jurídica entre consumidor-usuario y el empresario o comercio, siempre que las partes intervinientes se sumerjan en los conceptos legales que les atribuyen tal posición en una relación jurídica (art. 1-2 $2^{\circ}$ de la LGDCU, y actual art. 1 de la LCC que también realiza una definición en este sentido -el último añadido es nuestro-) que por su real y aparente desigualdad ha configurado toda una legislación proteccionista. Sigue añadiendo el autor (págs. 175-176) que se trata de claúsulas que vienen impuestas al cliente, consumidor o usuario por una empresa, y que deseando obtener el bien o servicio, vendrá abocado a concluir el contrato sin entrar a discutir sobre el contenido del mismo. Le vienen dadas a una de las partes las reglas de comportamiento contractual, contenido del contrato, modalización de sus efectos, etc. 
ción no puede evitar el consumidor o usuario, siempre que quiera obtener el bien o servicio de que se trate». Estipulaciones, cláusulas o pactos de carácter «general» que habían de conjugarse con las que tuviesen, en su caso, carácter «particular» y que el art. $10-2^{\circ}$ in fine de la misma Ley declaraba prevalentes si eran más beneficiosas para el comsumidor (precepto que se completaba con el art. $8-2^{\circ}$ de la Ley que igualmente declaraba tal prevalencia cuando éstas clásulas formaban parte del contenido de la oferta, promoción o publicidad).

Actualmente, la vigencia de la reciente LCGC de 1998 viene a modificar el marco jurídico preexistente de protección al consumidor, que hasta ahora quedaba englobado en la LGDCU de 1984, la cual queda modificada en los términos de la Disposición Adicional $1^{a}$ de la nueva Ley, que subraya con especial énfasis la diferencia entre las claúsulas abusivas y las condiciones generales de la contratación. Así, la nueva Ley define las condiciones generales de la contratación en su art. 1-1 $1^{\circ}$ como: «...las claúsulas predispuestas cuya incorporación al contrato sean impuesta por una de las partes, con independencia de la autoría material de las mismas, de su apariencia externa, de su extensión y de cualesquiera otras circunstancias, habiendo sido redactadas con la finalidad de ser incorporadas a una pluralidad de contratos». Únicamente añadir -y dado que nuestro trabajo no abarca el estudio de esta nueva normaque la misma será de aplicación a los contratos sometidos a la LVPBM en tanto que el contenido de éstos incluyan condiciones generales de la contratación y las partes que lo otorgan, en principio, también queden sometidas al ámbito subjetivo de la Ley (art. 2 de la LCGC).

El segundo aspecto, de evidente carácter imperativo, resulta claramente excepcional, máxime a la vista de la regulación general de los contratos de compraventa en el Código Civil. Es lo que se ha venido denominando como contenido «mínimo» obligatorio, y que aparece recogido con carácter taxativo en la propia LVPBM (art. 7), la cual recoge hasta 14 circunstancias (incluso si tenemos en cuenta lo dispuesto en el art. $6-3^{\circ}$ de la LCC, éstas podrían ampliarse por vía reglamentaria), de las cuales, la mayoría de ellas guardan cierta similitud con el anterior art. 6 de la Ley de 1965 (y con el art. 6-2 ${ }^{\circ}$ de la LCC ${ }^{32}$ ), si bien conviene poner de manifiesto las diferencias en cuanto a los supuestos recogidos:

32 Dicha similitud en este supuesto es, sin embargo, una similitud relativa, porque: a) el art. 6$2^{\circ}$ de la LCC no contiene la parte dispositiva que sí se expresa en la LVPBM, la cual deja a la voluntad de las partes la redacción de una parte del contenido del contrato (en el mismo sentido que el art. $1255 \mathrm{CC}$ ) pero siempre respetando la otra parte del contrato, de contenido mínimo obligatorio. b) El art. $6-2^{\circ}$ de la LCC utiliza la expresión «...además de las condiciones esenciales del contrato...», la cual no se contiene en la LVPBM. Esta expresión nos resulta ciertamente desafortunada, pues no parece que con la misma se esté haciendo referencia a los requisitos esenciales de los contratos (art. 1261 del CC); más bien habría de entenderse que el legislador ha querido aludir a los «datos esenciales» del contrato, tales como identificación de las partes, tipo de las operaciones, plazo, etc. (en este sentido ROCA GUILLAMÓN: «Los contratos...», 
a) El apartado $1^{\circ}$ no sufre alteración alguna, y alude al lugar y fecha del contrato. Sí se modifica y se muestra con más amplitud el párr. $2^{\circ}$ al incluir, además de los datos personales de las partes intervinientes (que era el único contenido de la antigua circunstancia $2^{\mathrm{a}}$ ), los datos personales del financiador, así como los datos de identificación fiscal de todos los intervinientes.

b) El apartado $3^{\circ}$, relativo a la descripción del objeto, permanece de forma idéntica; en cambio, el párr. $4^{\circ}$, relativo al pago del precio, contiene una importante diferencia con la regulación anterior al establecer el desembolso inicial con carácter potestativo (cuando anteriormente el desembolso inicial era una circunstancia esencial del contrato determinante de su perfección); a la vez que aglutina en un sólo precepto lo que antes se contenía en los apartados $4^{\circ}, 5^{\circ}$ y $6^{\circ}$ (Ley de 1965).

c) Los apartados $5^{\circ}$ a $8^{\circ}$ introducen importantes novedades (a diferencia de la regulación contenida en los anteriores apartados $7^{\circ}$ a $10^{\circ}$ ), cuando se trate de una operación sometida al pago de intereses (fijo o variable). Entre otras figuran: la determinación y descripción de las operaciones con interés (ap. $5^{\circ}$ y $6^{\circ}$, y art. $6-2^{\circ}$ b) de la LCC); la indicación de la «tasa anual equivalente» (ap. $7^{\circ}$ ) que aparece recogida también por el art. $6-2^{\circ}$ a) de la LCC como contenido obligatorio de los contratos sujetos a dicha Ley, y asímismo definida en el art. 8 de la misma Ley; y el concepto de «coste total del crédito» y los elementos que lo componen (ap. $8^{\circ}$, y art. $6-2^{\circ} \mathrm{c}$ ) de la LCC, que añade algunos elementos más -seguro de amortización del crédito por fallecimiento, invalidez, enfermedad o desempleo del titular, en su caso-), a su vez definido en el art. 18 de la LCC ${ }^{33}$, y con posibilidad de su modificación en virtud de lo establecido en el art. 8 de esta misma Ley). Por lo demás, queda suprimida, de forma novedosa, toda referencia a los «recargos» u otras circunstancias de la misma índole recogidas en la Ley anterior (ap. $8^{\circ}$ y $14^{\circ}$ ). Con ello se persigue cumplir una

cit., pág. 160). c) En lo que sí parecen coincidir ambas normas es en calificar como «contenido obligatorio» (la LCC dice «...el documento contendrá necesariamente...», mientras que la LVPBM dice «...contendrá con carácter obligatorio...») a una serie de circunstancias, algunas coincidentes, que cada una de estas leyes enumera taxativamente, siendo más extensa la enumeración que realiza la LVPBM.

33 Art. 18 de la Ley de Crédito al Consumo:

«a) Se entenderá que el coste total del crédito comprende los intereses y todos los demás gastos y cargas que el consumidor esté obligado a pagar para el crédito, incluidos los de seguros de amortización del crédito por fallecimiento, invalidez, enfermedad o desempleo del titular, que sean exigidos por el empresario para la concesión del mismo.

b) Se entenderá por tasa anual equivalente el coste total del crédito, expresado en un porcentaje anual sobre la cuantía del crédito concedido.

La tasa anual equivalente igualará, sobre una base anual, el valor actual de todos los compromisos (créditos, reembolsos y gastos) existentes o futuros asumidos por el empresario y por el consumidor, y se calculará de acuerdo con la fórmula matemática que se expresa en el anexo». 
finalidad muy concreta: que no se produzcan efectos perturbadores en el consumidor estableciendo índices de diferente naturaleza, quedando como punto de referencia más adecuado el de los tipos de interés 34.

Estas tres circunstancias (tasa anual equivalente, coste total del crédito y tipo de interés) además de su constancia obligatoria en el contenido del contrato debe también ponerse de manifiesto en la publicidad sobre las ofertas de crédito (art. 13 de la LVPBM y art. 17 de la LCC).

d) Por último, los apartados $12^{\circ}, 13^{\circ}$ y $14^{\circ}$ son de nueva redacción. De éstos adquiere especial trascendencia la facultad de desistimiento regulada de forma específica en el art. 9 de la Ley (antiguo art. $8^{\circ}$ ) con una amplitud de la que carecía la Ley anterior, y que analizamos más adelante.

Podemos decir que la LVPBM en este precepto contiene una enumeración de circunstancias obligatorias ciertamente exhaustiva, en tanto que la LCC ha querido dotar de este carácter únicamente a aquellas que considera de especial relevancia: a) la tasa anual equivalente que constituye la pieza central del sistema de información y protección de los consumidores; b) el importe, número y periodicidad de los apgos a realizar por el consumidor para reembolsar el crédito, el pago del interés y demás gastos; c) los elementos que componen el coste total del crédito.

Por último, el art. 8 (antiguo art. 7) consituye una norma sancionadora del art. 7 y es el que se encarga de establecer el régimen de penalizaciones por omisión o expresión inexacta de tales claúsulas obligatorias 35 consistente en la reducción o modulación de obligaciones y no exigibilidad de los pagos o gastos en las condiciones iniciales, y en función del tipo de cláusula afectada de entre las mencionadas en el artículo anterior y de las circunstancias en que tal omisión o expresión inexacta se haya producido. Se ha establecido, pues, un sistema de sanciones de tipo económico

34 No obstante, algún vestigio ha quedado de la referencia al «recargo» a la vista del art. 11 de la nueva Ley relativa a la facultad moderadora de Jueces y Tribunales, en su párr. $1^{\circ}$ : «...podrán señalar nuevos plazos o alterar los convenidos, determinando, en su caso, el recargo en el precio por los nuevos aplazamientos de pago», que únicamente se explicaría por la repetición casi exacta que el legislador de la Ley de 1998 ha hecho de la Ley de 1965, con relación a muchos de sus preceptos.

$35 \mathrm{El}$ art. 7 de la LCC establece asímismo el sistema de penalizaciones para el supuesto de que se produzca el incumplimiento de alguno de los supuestos del art. $6^{\circ}$, pero utilizando una terminología algo diferente a la de la LVPBM, bajo la expresión «Penalizaciones por falta de forma y por omisión de cláusulas obligatorias», pero que igualmente acoge un sistema de reducciones y modulaciones de la obligación de pagar intereses o del pago del propio crédito. Únicamente destacar un dato diferenciador: el art. 7 LCC impone expresamente la sanción de nulidad por incumplimiento de la forma escrita mientras que la LVPBM no menciona dicha sanción, simplemente la omite. 
que lleva a la aplicación imperativa de la ley, alejando la sombra de otro tipo de sanciones, en especial de aquellas que pudieran llevar aparejada la nulidad del contrato.

\subsection{Cláusulas ineficaces}

El art. 14 de la Ley se ha redactado en términos idénticos al art. 18 de la Ley de1965, y de forma similar al art. 3 de la LCC. Es la norma que completa y cierra el régimen general de eficacia regulado por el art. 6. A tal efecto, se sanciona con la ineficacia o nulidad parcial (el precepto dice «Se tendrán por no puestas...») a aquellas claúsulas, pactos o condiciones que aún incorporadas al contrato sean contrarias a los preceptos de la propia Ley o se dirijan a eludir su cumplimiento ${ }^{36}$.

Sin embargo, tampoco podemos obviar que la nueva LCGC va a dejar sentir su influencia sobre tal precepto, siempre que en estos contratos se incluyan condiciones generales de la contratación para lo cual habrá de tener en cuenta fundamentalmente sus arts. 6 (reglas de interpretación), 7, 8, 9 y 10 (sobre no incorporación y nulidad de condiciones generales), pero en lo que de momento no podemos entrar.

\subsection{La facultad de desistimiento del comprador}

La nueva Ley dedica a este tema una gran extensión, y a la vista está el art. 9 que regula expresamente la facultad de desistimiento del comprador (a la vez que le da título al precepto), y las importantes diferencias respecto a la regulación anterior (art. 8). Diferencias que sintetizamos en las siguientes:

a) La facultad de desistimiento por el comprador ve ampliado el plazo para su ejercicio de tres a siete días ${ }^{37}$, siempre y cuando se cumplan «todos» los requisitos legalmente exigidos. En este sentido, el precepto en su párrafo $1^{\circ}$ apartados a) y b)1 , coincide exactamente con el contenido del antiguo art. 8, excepto en el dato añadido de que el comprador ha de comunicar su desistimiento no sólo al vendedor sino también al financiador, en su caso, cuando el anterior precepto sólo se refería al vendedor. Los apartados c) y d) del párr. $1^{\circ}$, relativos al derecho del vendedor a ser indemnizado por la eventual depreciación del bien, y la obligación del comprador de reintegrar el préstamo en el supuesto del art. $43^{\circ}$, son de nueva redacción.

36 Como dice BERCOVITZ: Comentarios..., cit., pág. 252, citando a BALDO, «Toda claúsula que determine una alteración de dicho equilibrio de intereses debe ser considerada como inexistente de acuerdo con el precepto (art. 18 antiguo)».

37 Este plazo de siete días coincide con el que establece la LOCM en su art. 10-2 ${ }^{\circ}$, que igualmente recoge el derecho de desistimiento del comprador a propósito de la oferta comercial en general; y asimismo el art. $44-1^{\circ}$ en el caso de ventas a distancia. 
b) El párr. $2^{\circ}$ también es de nueva redacción, introduciendo como importante novedad la facultad de desistimiento, configurado como un derecho de carácter irrenunciable, aún cuando no conste expresamente en el contrato. No es preciso, pues, que se pacte expresamente para que el comprador tenga derecho a ejercitarlo, como ocurría con antrioridad (art. 8: «Si se hubiera pactado...») que sí debía formar parte del contrato para proceder a su ejercicio.

c) El párr. $3^{\circ} 38$ (que sustituye al antiguo art. 10 con algunas variaciones) concede al comprador la posibilidad de realizar el pago o reembolso anticipado del precio pendiente, total o parcialmente; lo que sin duda modaliza el régimen general establecido en los arts. 1125 y 1127 del Código Civil, según los cuales el acreedor no queda obligado al pago anticipado. Solución jurídica que se explicaría por la preponderancia que esta Ley dispensa a la protección al consumidor. Las principales diferencias respecto a la regulación anterior en esta cuestión son:

Primero, el precepto actual permite, una vez trascurrido el plazo para el ejercicio de la facultad de desistimiento, que el comprador pueda «en cualquier momento de vigencia del contrato» realizar el pago anticipado del precio pendiente, total o parcialmente (el anterior art. 10 permitía dicho pago anticipado en un momento muy concreto: al vencimiento de cualquiera de los plazos, y con relación a la parte del precio pendiente); si bien con una salvedad: si es parcial, no podrá ser inferior al $20 \%$ del precio, salvo pacto (matización que no se recogía en la Ley anterior).

$\mathrm{Y}$, segundo, al comprador se le concede una reducción cuantitativa en el pago de intereses, no quedando obligado al pago de intereses no devengados por el hecho del pago anticipado, excepto si se hubiese pactado compensación. Si, por el contrario, se pacta una compensación, ésta opera con unos límites máximos: no podrá exceder del $1,5 \%$ en los contratos bajo interés variable y del $3 \%$ en los de interés fijo ${ }^{39}$. En consecuencia, el legislador parece que ha querido evitar todo signo de enriquecimiento

38 Redactado de forma muy similar al art. 10 de la LCC, aunque con algunas diferencias, como las de utilizar la expresión «reembolso» en vez de «pago», o la no utilización de los términos «interés variable» 0 «interés fijo» que sustituye por los de contratos «con» 0 «sin» modificación del coste del crédito. Sí coinciden ambas en señalar como compensación por el reembolso o el pago anticipado los mismos porcentajes: el 1,5 y el 3\%, respectivamente. Y lo que no se recoge, en la LCC, es la limitación del $20 \%$ con carácter mínimo para los pagos parciales anticipados, salvo pacto.

39 La diferencia entre estos porcentajes en la reducción de intereses tiene su justificación en los distintos perjuicios que se puedan ocasionar a la entidad financiadora. Así, en los créditos a interés variable el daño es menor porque el interés pagado por el consumidor se modula con arreglo a la evoulción real del mercado; por el contrario, en los créditos a interés fijo no se producen variaciones, generando a la entidad mayor seguridad tanto en la rentabilidad que producirá la operación como en su posible movilización (cfr. ANDREU MARTÍ: El cliente..., cit., pág. 168). 
injusto por el vendedor o prestamista, que de hecho se produciría si el comprador tuviese que reembolsar la totalidad de los intereses del precio aplazado. $Y$ éste parece ser el principal motivo que ha llevado a la desaparición de los gastos y recargos que el anterior art. 10 , apartados $1^{\circ}$ y $2^{\circ}$ le atribuía al comprador.

d) La única excepción que cabe oponer a dicha facultad es la establecida en el párr. $4^{\circ}$ : cuando la adquisición aplazada por el comprador tiene por objeto vehículos de motor susceptibles de matriculación, en cuyo caso, la facultad de desistimiento puede ser objeto de exclusión, si existe pacto al respecto, e incluso se apunta la posibilidad de que dicha facultad se modalice de forma distinta a lo que se prevé para la misma con carácter general en la Ley.

\subsection{El incumplimiento por el comprador}

El art. 10 de la Ley es el que básicamente proporciona al vendedor los derechos (sin olvidar que también se le reconocen garantías, y que veremos más adelante) que le son reconocidos por su posición jurídica en el contrato (y, en su caso, igualmente al prestamista). El párr. $1^{\circ}$ contempla expresamente este supuesto, regulando la doble posibilidad para el vendedor de exigir el pago de todos los plazos pendientes o bien optar por la resolución del contrato ante el incumplimiento por mora del comprador de dos plazos o del último de ellos ${ }^{40}$. Dicho párrafo aparece redactado en casi los mismos términos que el anterior art. 11, respecto del que se ha variado únicamente la redacción del párr. $2^{\circ}$, apartado $2^{\circ}$ (consecuencia de la anterior obligatoriedad del desembolso inicial), a la vez que se ha suprimido el párr. $4^{\circ}$ (referido a las acciones de resarcimiento), que actualmente ya no se recoge.

Cuando el vendedor opte por la resolución del contrato, ante el incumplimiento por el comprador de sus obligaciones contractuales, la actual Ley sigue manteniendo la concesión de deducciones o indemnizaciones a favor de éste (o del prestamista, en su caso, y cuya referencia a él no se contenía en la redacción anterior que se circunscribía únicamente a la figura del vendedor) de forma precisa y concreta, ni más ni menos. En este sentido la redacción del precepto marcando el cuantum no deja lugar a dudas (apartados a) y b) del párr. $1^{\circ}$ ). Hay que destacar en esta sede que la

40 Vid. MARTÍNEZ DE AGUIRRE: Las ventas..., cit., págs. 86 y ss. y las conexiones que se pueden derivar entre este precepto y el art. 1124 del Código Civil.

Añadir además que el retraso por incumplimiento a efectos del art. 10 de la Ley hay que diferenciarlo del mero retraso en el cumplimiento -cualquier vencimiento del plazo que quede impagado-. El precepto no viene referido al mero retraso en el cumplimiento sino al incumplimiento efectivo, el cual se entiende que tiene lugar cuando se produce el impago de dos plazos o del último de ellos, sin necesidad de ningún otro requisito (vid. en este tema CRISTOBAL MONTÉS: La mora del deudor en los contratos bilaterales. Madrid 1984, págs. 61 y ss.). 
actual redacción de dicho párrafo, en el ap. b), es prácticamente idéntica a la anterior, con un importante añadido: «Cuando no exista el desembolso inicial, o éste sea superior a la quinta parte del precio de venta al contado, la deducción se reducirá a esta última»; lo cual no es sino la consecuencia lógica de la no obligatoriedad del desembolso inicial.

El párr. $2^{\circ}$ contempla, por otra parte, los derechos para el tercero que haya financiado la adquisición de los bienes muebles en los términos del art. 4 de la presente Ley ante la falta de pago de dos plazos o del último de ellos por el comprador, consistente en el abono de la totalidad de los plazos pendientes, sin perjuicio del ejercicio de sus derechos como cesionario del vendedor y de lo preceptuado en el art. 11 de la Ley.

El art. 9 de la LCC establece, en tales casos, un sistema de liquidaciones similar, haciendólo extensivo no sólo a los supuestos de resolución del contrato de adquisición o financiación, sino también a los supuestos de ineficacia del contrato respectivo. Tal sistema consiste en la restitución recíproca de las prestaciones realizadas con la finalidad de evitar supuestos de enriquecimiento injusto y desequilibrios patrimoniales. No obstante, se reconoce el derecho a practicar las deducciones previstas al empresario o prestamista al que no pueda imputársele la nulidad del contrato (matización que no realiza el art. $10-1^{\circ}$ de la LVPBM, en tanto que reconoce esas deducciones al vendedor o prestamista sin más, por el hecho de la resolución del contrato). Este precepto se completa con el art. 11 de la LCC que regula la cesión a un tercero de los derechos del concedente de un crédito; en cuyo caso, el consumidor (o comprador) podrá oponer contra el tercero las mismas excepciones que le hubieran correspondido contra el acreedor originario, inclusive, si procede, la compensación conforme al art. 1198 del CC.

\subsection{Competencia y función judicial}

La competencia judicial territorial que se prevé en el actual 12 ha diferido diametralmente del anterior art. 14. El art. 12 ha sido redactado de forma más precisa, concreta y acertada al establecer la competencia y conocimiento de los litigios relativos a los contratos regulados en esta Ley de los Jueces y Tribunales del domicilio del «demandado», cuando anteriormente se señalaba el domicilio del «comprador».

Este precepto, no obstante, puede entrar en conflicto con el art. 4 de la LCC que establece como Juez competente el del domicilio del «consumidor». Esta contradicción normativa, en principio, quedaría solventada mediante la aplicación preferente de la LCC (art. 4), siempre y cuando el demandado sea el consumidor, por el principio de protección que a éste se le dispensa en toda la legislacion sobre consumo; no 
solucionándose el supuesto de que el demandado sea el vendedor. Pero es más, también entra en contradicción con el art. 9-3 ${ }^{\circ}$ de la LCGC que establece como Juez competente el del domicilio del «demandante».

En este sentido, hay que hacer notar que el último párrafo del precepto (art. 12 de la LVPBM): «...siendo nulo cualquier pacto en contrario», que también existía en la regulación anterior, lo que hace es cerrar la posibilidad de estipular la sumisión expresa prevista en el art. 57 de la LEC. Y, por consiguiente, cuando se trate de contratos sometidos a la LVPBM parece que será de aplicación lo previsto en esta norma frente a las otras dos anteriores, dado su evidente carácter imperativo y la especificidad de su materia frente a la regulación más general de las otras normas.

En razón de esa competencia judicial, serán los Jueces y Tribunales del domicilio del demandado los que asuman las facultades que le atribuye el art. 11. Por un lado, en el párr. $1^{\circ}$ se establece la facultad de señalar nuevos plazos o alterar los ya convenidos así como los recargos en el precio por dichos aplazamientos en determinados casos (en una redacción idéntica al antiguo art. 13); y por otro lado, el párr. 2, señala la facultad moderadora de las claúsulas penales pactadas en caso de pago anticipado o incumplimiento del comprador (precepto que no aparecía en la redacción anterior). Dichas facultades, no obstante, son de ejercicio restringido, al establecerse en el precepto su carácter «excepcional» y sólo por «causas justificadas apreciadas discrecionalmente» (el precepto ejemplifica como tales causas las desgracias familiares, el paro, los accidentes de trabajo, una larga enfermedad y otros infortunios), con un contenido, por otro lado, muy similar al del art. $1124-3^{\circ}$ del Código Civil.

\subsection{La publicidad en el «precio» de los bienes objeto de esta Ley}

El art. 13 de la Ley 28/1998 ha venido a sustituir al anterior art. 15, y si bien el precepto ab initio es semejante ( «La publicidad relativa al precio de los bienes ofrecidos en venta a plazos deberá expresar el precio de adquisición al contado y el precio total a plazos....»), el resto carece de tal semejanza.

Actualmente, el párr. $1^{\circ}$ establece de forma precisa que el contenido de dicha publicidad debe expresar, si se ha estipulado un tipo de interés variable, el precio estimado total según el tipo vigente al momento de la celebración del contrato. Es ésta una obligación informativa de carácter precontractual ${ }^{41}$ que asume el vendedor 0

41 Esta función informativa en período precontractual obliga al vendedor o empresario no sólo a establecer un contenido mínimo de la publicidad que se realice, sino que además la oferta realizada le obliga a la realización del contrato que posteriormente se realice individualmente con arreglo a ese contenido mínimo (arts. 17 y 18 de la LCC). Vid. sobre esta cuestión y colaterales ANDREU MARTí, M.M.: El cliente bancario. Madrid 1998, págs. 156 y ss. 
empresario que fija su oferta en locales comerciales, y únicamente referida a la información sobre el precio; se obvia toda referencia a otras circunstancias del contrato.

El párr. $2^{\circ}$, que no hace sino reproducir el tenor casi literal del art. 17 de la LCC, se refiere a un supuesto muy concreto: la publicidad, anuncios y ofertas exhibidos en locales comerciales cuando ofrezcan un crédito o la intermediación para la celebración de un contrato sujeto a esta Ley. En este caso la ley establece de forma obligatoria ( bajo la expresión «...deberá, en todo caso...») que se indique el tipo de interés 42 y la tasa anual equivalente, y ello mediante un ejemplo representativo. Conceptos ambos que la Ley de 1995 define en su art. 18.

Estos preceptos se conectarán con las normas respectivas de la LOCM cuando haya que informar de las actividades de promoción de ventas (si éstas son a plazos) mediante anuncios (arts. 19, 20, 29, entre otros), y con la Disposición Adicional $1^{\mathrm{a}}$ de la LCGC que modifica el art. 10-1 ${ }^{\circ}$ de la LGDCU, y que se refiere a los requisitos (art. 10-1 $\left.\left.1^{\circ} \mathrm{a}\right), \mathrm{b}\right)$ y c)) que deben cumplir «Las claúsulas, condiciones y estipulaciones que se apliquen a la oferta o promoción de productos o servicios, y las claúsulas no negociadas individualmente relativas a tales productos o servicios, incluidos los que faciliten las Administraciones públicas y las entidades y empresas de ellas dependientes...».

\section{El Registro de Venta a Plazos de Bienes Muebles y otras garantías}

\subsection{El Registro de Venta a Plazos de Bienes Muebles}

El legislador de la nueva Ley ha pretendido no sólo aproximar el régimen de garantías recogido para las ventas a plazos al que se reconoce en el ámbito inmobiliario, sino que además ha querido dejar patente la trascendental importancia que ha de atribuirse al Registro de Ventas a Plazos de Bienes Muebles, así como a los efectos de los actos que en él se inscriban, con un precepto ciertamente amplio (art. 15 de la LVPBM). No sólo porque en su párr. $2^{\circ}$ transcribe literalmente el art. $38 \mathrm{de} \mathrm{la}$ Ley Hipotecaria, sino porque además la nueva Ley ha mantenido expresamente en vigor la norma que lo regulaba (Orden de 15 de Noviembre de 1982 por la que se aprueba la nueva Ordenanza para el Registro de Ventas a Plazos de Bienes Muebles, a su vez sustitutoria de la Orden de 8 de Octubre de 1966) en todo lo que no se oponga a la presente Ley (Disposición Derogatoria Única, ap. $4^{\circ}$ de dicha Ley); la cual, tanto en su Exposición de Motivos como en la Disposición Adicional $3^{\mathrm{a}}$, destaca y pine de relieve que el citado Registro «...se "integrará" en el futuro Registro de

$42 \mathrm{El}$ art. 17 de la Ley de 1995 indica que puede constar «... el tipo de interés o cualesquiera cifras relacionadas con el coste del crédito...». 
Bienes Muebles, a cargo de los registradores de la Propiedad y Mercantiles, conforme disponga su Reglamento» ${ }^{43}$. Añadir que si el contrato contiene condiciones generales de la contratación deberá proceder su inscripción en el Registro que a tal efecto regula la LCGC en su art. 11.

Debemos resaltar que la reciente LVPBM restringe el acceso a dicho Registro, permitiéndo la inscripción únicamente de aquellos contratos que tengan por objeto bienes muebles identificables, y sólo ellos se beneficiarán de las garantías de su inscripción (principio de especialidad).

Por último, el legislador ha previsto asimismo una serie de mecanismos con el objeto de facilitar al vendedor el cobro de sus créditos como, por ejemplo, ocurre con la determinación del tipo de la primera subasta en el precio de venta al contado si, a este efecto, las partes no han fijado otro en el contrato. Y, derivada de la inscripción registral, ante cualquier tipo de incumplimiento, los contratos que hayan sido registrados gozan de fuerza ejecutiva, que es un procedimiento mucho más rápido.

\subsection{Otras garantías: Especial referencia a la claúsula de reserva de dominio (pactum reservati dominii)}

Las garantías reconocidas en la LVPBM, que desde una visión general de las mismas debemos entenderlas referidas tanto al contenido obligatorio del contrato (en concreto el art. $7-10^{\circ}$ y $11^{\circ}$ ) como a la estricta función de garantía y eficacia erga omnes en virtud de su inscripción en el Registro (art. 15), se constituyen para asegurar el cumplimiento de las obligaciones nacidas de los contratos de venta a plazos de bienes muebles y de los de préstamo destinados a facilitar su adquisición (en expresión del art. $11^{\circ}$ ). Son fundamentalmente la cláusula de reserva de dominio y la prohibición de disponer ${ }^{44} \mathrm{y}$, aunque ambas son de diversa naturaleza, producen un

43 Norma que ha de coordinarse con la Disposición Final $2^{\mathrm{a}}$ de la Ley $19 / 1989$, de 25 de Julio, de Reforma parcial y adaptación de la legislación mercantil a las Directivas comunitarias, y que contempla la refundición en un único Registro de la Propiedad Mobiliaria del Registro de Venta de Bienes Muebles a Plazos del Libro de Buques y Aeronaves y del registro de Hipoteca Mobiliaria y Prenda sin Desplazamiento.

44 Es normal y habitual que en el mismo contrato concurran ambas garantías aunque la eficacia de la reserva de dominio aborbe normalmente a la prohibición de disponer (si a ello añadimos que desde el punto de vista procesal también se encuentra en una clara posición de desventaja). Como vamos a detenernos brevemente en el pacto de reserva de dominio por su relevancia, respecto de la prohibición de disponer señalar únicamente que sus consecuencias, una vez inscrita en el Registro, se dirigen a provocar la nulidad de pleno derecho de la disposición realizada por el comprador cuando la contravengan; y con ello la facultad del vendedor para pedir la nulidad del acto o contrato en que se hubiera producido dicha disposición. Como corolario a esta situación se produciría el retorno de la cosa vendida al patrimonio del comprador, y 
efecto idéntico un vez inscritas: desvirtuar la presunción de buena fe del tercero para que su derecho no prevalezca sobre el derecho del vendedor o financiador; así como consecuencias similares: nulidad de los actos de disposición que la contravengan, incluso, si proceden de la autoridad judicial, aunque por medio de instrumentos jurídicos diferentes. Sin embargo, es la reserva de dominio la que constituye la pieza angular y toda una institución en este tipo de ventas y por ello hemos querido detenernos, siquiera brevemente, en ella.

A pesar de su larga y difícil trayectoria tanto doctrinal 45 como jurisprudencial ${ }^{46}$, la Ley de 1965 constituyó la primera norma que reconoció de forma expresa la virtualidad de esta claúsula, continuando la nueva Ley con dicho reconocimiento y en la misma línea normativa.

Dado que, actualmente, esta cláusula se ha regulado en los mismos términos que la Ley de 1965 (básicamente los arts. 19 y 23, y que la Ley actual de 1998 recoge en los arts. 15 y $16-5^{\circ}$ ), las polémicas doctrinales que en su día se suscitaron acerca de su eficacia, naturaleza jurídica o su auténtica función, podemos decir que hoy en día mantienen su vigencia.

Acerca de su naturaleza jurídica existen básicamente dos formulaciones mayoritarias. De un lado, la más clásica que asimila al pacto de reserva de dominio con la

de este modo seguir garantizando al vendedor o financiador bien la devolución del bien (si opta por la resolución), bien las preferencias del art. $16-5^{\circ}$ (si opta por el cumplimiento).

45 Cfr. CANDIL: Pactum reservati dominii. Madrid 1925; OERMANN: «La reserva de dominio en la compraventa (Pactum reservati dominii)», RDP/1930; POMPEYO CLARET: «El contrato de compraventa con reserva de dominio según la legislación y la jurisprudencia española», RDP/1930; BLANCO: "Venta con reserva de dominio», RDP/1947; VÁZQUEZ RICHART, J.: La compraventa a plazos (de los bienes muebles). Madrid 1963, págs. 171 y ss.; BULLÓN, S.: Las ventas a plazos según la nueva Ley. Madrid 1966; BERCOVITZ: Las ventas a plazos..., cit., págs. 127 y ss.; también en La Ley sobre venta de bienes..., cit., pág. 243, y de forma más específica en La claúsula de reserva de dominio. Estudio sobre su naturaleza jurídica en la compraventa a plazos de bienes muebles. Madrid 1971, pág. 17; SOTO NIETO: Derecho vivo..., cit., págs. 484 y ss.; ZUMALACÁRREGUI: «El Registro de reservas de dominio de bienes muebles vendidos a plazo», RCDI/1974, págs. 551 y ss.; TORRES LANA: «Notas críticas...», cit., págs. 630 y ss.; EGUSQUIZA BALMASEDA, M.A.: «Sobre el pacto de reserva de dominio (a propósito de la Sentencia de 19 de Mayo de 1989)», RCDI/1991, págs. 9 y ss. Más recientemente RIVERA FERNÁNDEZ, M.: La posición del comprador en la venta a plazos con pacto de reserva de dominio. Valencia 1994.

46 La jurisprudencia admitió su empleo en el negocio jurídico de compraventa con precio aplazado, sobre todo si tenía por objeto bienes de carácter mueble, desde antiguo (SSTS de 16 de Febrero de 1894, 6 de Marzo de 1906, 1 de Diciembre de 1909, 13 de Diciembre de 1911, etc.), considerando que era posible y lícita en virtud de la libertad concedida a los contratantes por el art. 1255 del Código Civil. 
condición suspensiva ${ }^{47}$ y, de otro lado, la elaborada posición de BERCOVITZ ${ }^{48}$ (restringida al ámbito legal y difícilmente aplicable a los contratos excluídos de la misma y no inscritos) por la base legal sobre la que se asienta, es decir, la propia Ley de ventas a plazos y la posición privilegiada que asumen los acreedores preferentes de los arts. $1922-2^{\circ}$ y $1926-1^{\circ}$ del Código Civil a los que se remite expresamente la actual Ley en su art. $16-5^{\circ}$ (lo que también hizo la Ley anterior en su art. 19, y en los mismos términos). Esta autor parte de la idea de que la prenda puede cubrir los supuestos, contenido y funciones desempeñadas por el pacto de reserva de dominio, y por tanto son asimilables (entre otras similitudes estarían el respeto a la prohibición del pacto comisorio o la falta de desplazamiento a favor del acreedor-vendedor que aquí queda sustituída por la publicidad registral ${ }^{49}$ ).

Otro criterio al que se ha acudido, en torno a su naturaleza jurídica es aquél que ve en el pacto de reserva de dominio un tipo de condición resolutoria, tomando como base el funcionamiento de dicho pacto a propósito de la compraventa de bienes inmuebles 50; sin embargo las consecuencias que se derivarían de tal afirmación serían las mismas que si no mediase el pacto de reserva de dominio, de ahí la escasa utilidad de este criterio.

No obstante, la jurisprudencia relativamente reciente, aunque ha resuelto de forma diversa, parece decantarse por la primera formulación que atribuye al pacto de reserva de dominio la naturaleza propia de la condición suspensiva, fundamentándose en criterios tales como el principio de libertad contractual, la Ley 483 del Fuero de Navarra que lo configura de este modo, o el hecho de que dicha cláusula actúa

47 Postura sostenida por CABANILLAS, P.: «Discurso en Cortes de la Ley de venta de bienes muebles a plazos, presentado por el Minsterio de Justicia», RCDI/1965, págs. 1139 y ss.; y seguido por ALONSO PÉREZ: El riesgo en el contrato de compraventa. Madrid 1972, págs. 363 y ss.; TORRES LANA: «Notas críticas...», cit., págs. 631 y ss.; MARTÍNEZ DE AGUIRRE: Las ventas a plazos..., cit., págs. 100 y ss.

48 Vid. BERCOVITZ: «Las ventas a plazos de bienes muebles», ADC/1966, págs. 117 y ss.; La claúsula de reserva de dominio. Estudios sobre su naturaleza jurídica en las compraventas de bienes muebles. Madrid 1971, págs. 46 y ss.; Comentarios a la Ley de Ventas de Bienes Muebles a Plazos. Madrid 1977; «Comentario a la STS de 11 de Junio de 1983», CCJC n 3, págs. 873 y ss.; «Comnetario a la STS de 26 de Marzo de 1984», CCJC n 5, págs. 1541 y ss.; «Comentario a la STS de 19 de Mayo de 1989», $\mathrm{CCJC} \mathrm{n}^{\circ} 20$, págs. 571 y ss.; seguido de cerca por BALDO DEL CASTAÑO: Régimen jurídico..., cit.; de forma implicita SANTOS BRIZ: Derecho de cosas. Madrid 1973, págs. 685 y ss. que, aunque no se pronuncia expresamente, estudia la reserva de dominio como derecho real de prenda y la incluye dentro de los derechos de garantía mobiliaria.

49 Cfr. BERCOVITZ: La claúsula..., cit., págs. 43 y ss.

50 Vid. en este sentido CASAS VALLÉS: «La reserva de dominio en la venta de inmuebles», RJC/1986, págs. 641 y ss.; DÍEZ-PICAZO: Fundamentos de Derecho Civil patrimonial, II. Madrid 1986, págs. 82 y ss. 
condicionando únicamente la transmisión de la propiedad, no el negocio jurídico celebrado. Y así lo puso de relieve la relevante STS de 19 de Mayo de 1989 51 (alejada de la línea jurisprudencial que se abrió con la STS de 11 de Junio de 1983, cuya linea argumental atribuía la propiedad al vendedor en tanto que el comprador no cumpliese la condición suspensiva ${ }^{52}$ ), cuyos considerandos resumieron como formulación más adecuada la construcción jurídica del pacto de reserva de dominio como condición suspensiva ${ }^{53}$, y que si bien ésta recaía sobre bienes inmuebles, pensamos que no existe inconveniente en predicar la misma solución respecto de los bienes muebles, en tanto que el pacto de reserva de dominio cumple un estricto papel de garantía.

51 Sentencia que vino a confirmar lo expuesto en la SAT de Bilbao de 4 de Junio de 1987, al criticar lo expuesto en la STS de 11 de Julio de 1983 por la desventaja en que se dejaba al comprador si se aceptase la ejecución para los acreedores del vendedor: «...la posición del comprador estaría entonces a merced no ya del cumplimiento de sus obligaciones, sino de la situación jurídica del vendedor... y que el adquirente con reserva de dominio que cumple con sus obligaciones puede ser privado del bien por terceros acreedores del vendedor».

52 Postura jusrisprudencial que ha sido criticada por BERCOVITZ: CCJC n 3, págs., 873 y ss., y que creemos de absoluta justicia; también EGUSQUIZA: «Sobre el pacto...», cit., pág. 36, al considerar que la consecuencia de la tesis expuesta por el Supremo es que la reserva de dominio únicamente desplegaría sus efectos a favor del vendedor, ya que el comprador sujeto a aquella logrará la adquisición de la propiedad del bien solamente si lleva a cabo el pago del precio, y no se produce en el ínterin ejecución alguna del bien, por él detentado, por parte de los acreedores del vendedor. En contra de la postura de BERCOVITZ, TORRES LANA: «Notas críticas...», cit., pág. 634, para quien la cláusula de reserva de dominio mantiene la propiedad de la cosa en el vendedor o su cesionario.

53 Resumiendo y destacando lo más esencial de esta Sentencia, en su considerando $3^{\circ}$ se expone que: «... se somete a la resolución de esta Sala un mismo y único problema, cual es el de si el comprador de un bien inmueble... a precio aplazado y con pacto de reserva de dominio, a favor del vendedor hasta que quede totalmente pagado el precio, que se halla en posesión del inmueble comprado, por habérselo entregado el vendedor y que va cumpliendo exacta y puntualmente su obligación de pago en los respectivos vencimientos de los plazos estipulados, puede ejercitar la acción de tercería de dominio ante un embargo trabado, antes del vencimiento de todos los referidos plazos, sobre dicho inmueble por un acreedor del vendedor para el cobro, por la vía de apremio, de las deudas que éste tiene contraidas en favor de ese acreedor. La solución que corresponde al enunciado problema..., entendemos que ha de ser afirmativa, y ello con base en las siguientes consideraciones: a) la acción de tercería de dominio, que no puede ser identificada con la reivindicatoria, aunque presenta ciertas analogías con ella, tiene por finalidad principal no ya la obtención o recuperación del bien, que generalmente posee el propio tercerista, sino el levantamiento del embargo sobre el mismo... o, lo que es igual, sustraer de un procedimiento de apremio bienes no pertenecientes al patrimonio del apremiado...; b) aunque carente de regulación legal (salvo las referencias de la Ley de ventas a plazos de bienes muebles) el pacto de reserva de dominio..., viene a constituir simplemente..., una garantía del cobro del precio aplazado, cuyo completo pago actúa a modo de condición suspensiva de la adquisición por el comprador del pleno dominio de la cosa comprada. Durante el período de la pendencia de la expresada condición..., se produce esta doble situación jurídica: por una parte, y desde el lado del comprador, éste..., carece en absoluto de poder de disposición o facultad transmisiva a un tercero, por lo que si, antes de haber completado el pago, dispone voluntariamente de ella o se ve forzado a tal transmisión..., el vendedor con base en el citado pacto de reserva de dominio, podrá ejercitar las acciones procedentes..., para obtener la recuperación de la cosa...; por otra parte, y desde el lado del vendedor, 
Dejando de un lado estas posiciones doctrinales en torno a su debatida naturaleza jurídica, no debemos obviar el hecho de que cuando un sujeto realiza un pacto de estas características, se pretende alguna finalidad concreta. En realidad lo que persigue no es tanto la satisfacción del crédito en sí como garantizar la posición contractual. El principio de seguridad del tráfico jurídico exige no sólo la tutela de la posición del vendedor respecto a los acreedores del comprador sino también la del comprador respecto de los acreedores del vendedor ${ }^{44}$. Por tanto, la función esencial que se quiere conseguir mediante este pacto no es otra que establecer-además de su configuración propia como claúsula de garantía- un cierto equilibrio en las posiciones de vendedor y comprador; lo que tras la nueva normativa en esta materia se ha traducido en un importante incremento de la protección al comprador como consumidor, tal y como estamos viendo a lo largo de este trabajo.

Una última pregunta (sin que ni mucho menos con ella agotemos este tema) que nos puede surgir en este tema es ¿cabe la posibilidad de que garantizar una compraventa de bienes muebles no sometidas a la Ley con el pacto de reserva de dominio? En principio parece que no existiría inconveniente alguno el admitir tal posibilidad en base al art. $1255 \mathrm{CC}$, aunque ello no implicaría la atribución de los mismos efectos jurídicos que a los contratos sometidos a la Ley. De tal modo que si atendemos al texto de la misma, observamos como su actual art. 15 «exige» la inscripción en el Registro de Ventas a Plazos de dicho pacto de reserva de dominio, si es que se pretende su oponibilidad frente a terceros, lo cual sólo será posible respecto de aquellos contratos sujetos a la Ley, y no lo será respecto de los contratos excluidos de la misma, en los que el posible pacto de reserva de dominio únicamente tendrá efectos inter partes ${ }^{55}$.

éste, pese al expresado pactum reservati dominii, carece igualmente de poder de disposición o facultad de transmisión de la cosa a un tercero, mientras que el comprador esté dando cumplimiento a la obligación del pago aplazado..., de tal manera que si, durante el expresado período de pendencia de la condición, el vendedor dispone voluntariamente de la cosa a favor del tercero o se ve forzado a ello..., el comprador..., no puede quedar inerme e indefenso ante esa situación a la que es totalmente ajeno... Ante la situación aquí contemplada..., es evidente que el único medio de que el comprador dispone para la conservación de su derecho..., es el ejercicio de la acción de tercería de dominio para el levantamiento del embargo trabado sobre la cosa, la cual no forma parte del patrimonio del vendedor apremiado, al no tener éste, como antes se ha dicho, la libre disposición de ella, sin que esto implique desvirtuación alguna del expresado pacto de reserva de dominio, el cual solamente podrá desplegar su verdadera efectividad, en cuanto simple garantía que es el pago del precio...».

54 Cuestión íntimamente relacionada con el ejercicio de la tercería de dominio, cuyo mecanismo procesal parece el más adecuado ante el embargo de terceros acreedores y puesto que el fín que persigue es el levantamiento del embargo (La jurisprudencia anterior permitía al vendedor el ejercicio de la tercería de dominio con el consiguiente efecto frente a los terceros acreedores de una cláusula que en principio sólo afectaba al ámbito interno de la relación contractual).

55 No obstante, MARTÍNEZ DE AGUIRRE: Las ventas a plazos de bienes muebles. Madrid 1988, págs. 137 y ss., duda de esta solución a la vista de la Jurisprudencia más antigua (cuando aún no estaba vigente la Ley de 1965 y la necesidad de inscripción que ésta imponía para la eficacia erga omnes) 


\section{El procedimiento a seguir en caso de incumplimiento del deudor}

Es el procedimiento a seguir ante el incumpliento del deudor el que más preocupación ha suscitado en el legislador, lo cual tiene su lógica explicación en la propia existencia y finalidad de la venta a plazos, cual es la situación de iliquidez del comprador en el momento de la adquisición que no permite el pago al contado. Preocupación que se manifiesta en la extensión dada al art. 16 mediante un detallado y exhaustivo enunciado ${ }^{56}$, y con un contenido muy semejante al anterior art. 19, sobre todo en sus párrafos $3^{\circ}, 4^{\circ}, 5^{\circ}$ y $6^{\circ}$ (actual párr. $2^{\circ}$ ) relativo al procedimiento de ejecución cuando se produzca el incumplimiento.

En concreto, el párr. $1^{\circ}$ recoge las consecuencias que el incumplimiento desencadena en el ámbito general del mismo con relación a las obligaciones contractuales (ejercicio de acciones declarativas y ejecutivas), para después excepcionar en su apartado $2^{\circ}$ que la acción ejecutiva sólo procederá cuando se trate de ventas a plazos de bienes muebles, debidamente inscritas, y si reunen las formalidades del art. 1429 de la Ley de Enjuiciamiento Civil ${ }^{57}$.

El párr. $2^{\circ}$ recoge el procedimiento de ejecución, que básicamente consiste en una subasta notarial (arts. 1872 y ss. de la Ley de Enjuiciamiento Civil) con la peculiaridad, respecto a la regulación anterior, de que en el ap. c), $\mathrm{n}^{\circ} 2$ se dice que: «En la primera subasta servirá como tipo el valor fijado a tal efecto por las partes en el contrato».

que aceptó la eficacia de tales pactos frente a terceros si tal situación entre comprador y vendedor constaba por escrito con fecha anterior a la ejecución, dado que aún no existían los medios de publicidad necesarios. Dicho autor entiende que cabría seguir manteniendo esta posibilidad, a propósito de la STS de 26 de Marzo de 1984. En contra BERCOVITZ: CCJC N 5 , págs. 1545 y ss.

56 Para MARTÍN BERNAL, J.M.: «Notas apresuradas sobre la Ley 28/1998, de Venta a Plazos de Bienes muebles», LA LEY/1998, este precepto es ciertamente desmedido en su redacción literal. Añadiendo este autor, respecto al contenido del mismo que, se hace necesario advertir que la determinación exacta de la deuda adquiere especial relevancia a efectos de la ejecución, sobre todo en aras de la protección del consumidor, pues las leyes que lo protegen nacen con ese designio.

57 Precepto ciertamente criticable en su redacción si tenemos en cuenta, como dice MARTíN BERNAL: «Notas apresuradas...», cit., que: «...la trascendencia del párrafo va mucho más allá al otorgar fuerza ejecutiva, a los efectos del art. 1429 de la Ley de Enjuiciamiento Civil, a los contratos debidamente inscritos en el Registro, pues... conviene resaltar que el acceso directo a esta oficina pública de documentos privados, que precisamente por el acto formal de su inscripción registral adquieren fuerza ejecutiva, constituiría una singular excepción al criterio general que viene rigiendo en nuestro Derecho en cuya virtud la ejecutividad de un título viene conferida no sólo por su inscripción en un Registro Público, sino por la precisa formalización en documento público como establece el art. 1216 de nuestro Código Civil, intervenido por fedatario público y dotado en consecuencia de las presunciones de autenticidad y veracidad, y hacen prueba (art. 1218 del Código Civil); y, que precisamente en razón de tal condición accede al Registro». 
Más conflictivo resulta el procedimiento cuando tales bienes se hallaren en poder de un tercero. En tal caso se le requerirá para el pago en los términos previstos por el precepto, distinguiendo una doble posibilidad: una, si el tercero paga, se subroga en el lugar del acreedor satisfecho, aunque «... si desamparase el bien, se entenderán con él todas las diligencias del trámite ejecutorio ya se siga éste ante fedatario público o en vía judicial, entregándosele el remanente que pudiera resultar después de pagado el actor»; y, otra, si el poseedor del bien se opone al pago o al desamparo, se seguirá lo dicho en la letra d) de este precepto, es decir, el tercero-acreedor podrá instar del Juez de Primera Instancia competente la ejecución sobre el bien o bienes adquiridos a plazos con arreglo a lo dispuesto en la LEC para el juicio ejecutivo, salvo las especialidades presentadas en este precepto.

El párr. $5^{\mathrm{a}}$ actual, en su primer apartado, igualmente aparece redactado en términos muy similares a los del párr. $1^{\circ}$ del anterior art. 19 , concediéndosele al acreedor la preferencia y prelación de sus créditos, según establecen los arts. $1922-2^{\circ}$ y 1926-1 ${ }^{\circ}$ del Código Civil. No obstante, tales derechos de prelación y preferencia, actualmente, se conceden no sólo a los contratos inscritos en el Registro de venta a plazos de bienes muebles (el anterior art. 19, párr. $1^{\circ}$ sólo recogía este supuesto), sino también a aquellos créditos nacidos de contratos otorgados en escritura pública o en póliza intervenida por Corredor de Comercio colegiado. El último apartado de este párrafo no ofrece mayor dificultad, y se expresa de forma idéntica a su redacción anterior (art. 19-2 $)$. 


\section{BIBLIOGRAFÍA}

ALBALADEJO, M.: Derecho Civil, T.II-1º. Barcelona 1989.

ALONSO PÉREZ: El riesgo en el contrato de compraventa. Madrid 1972.

ANDREU MARTÍ, M.M.: El cliente bancario. Madrid 1998.

ATAZ LÓPEZ, J.: Comentarios al Código Civil y Compilaciones Forales (Dir.

ALBALADEJO), T.XVII, vol. $1^{\circ}$ A (art. 1254). Edersa. Madrid 1993, págs. 1 y ss.

BALDO DEL CASTAÑO: Régimen jurídico de las ventas a plazos. Particular estudio de sus garantías. Madrid 1974

BERCOVITZ RODRÍGUEZ-CANO, R.: «Las ventas a plazos de bienes muebles», ADC/1966, págs. 117 y ss.

- La claúsula de reserva de dominio. Estudios sobre su naturaleza jurídica en las compraventas de bienes muebles. Madrid 1971.

- Comentarios a la Ley de Ventas a Plazos de Bienes Muebles. Madrid 1977.

- «Comentario a la STS de 11 de Junio de 1983», CCJC, n 3, págs. 873 y ss.

- «Comentario a la STS de 26 de Marzo de 1984», CCJC, nº 5, págs. 1541 y ss.

- «Comentario a la STS de 19 de Mayo de 1989», CCJC, nº 20, págs. 571 y ss.

BLANCO: «Venta con reserva de dominio», RDP/1947.

BULLÓN, S.: Las ventas a plazos según la nueva Ley. Madrid 1966.

CABANILLAS SÁNCHEZ, A.: «El leasing financiero y la Ley de Venta a Plazos de Bienes Muebles», $\mathrm{ADC} / 1980$, págs. 765 y ss.

CABANILLAS, P.: «Discurso en Cortes de la Ley de Venta a Plazos» (presentado por el Ministerio de Justicia), RCDI/1965 (XLI), págs. 1139 y ss.

CANDIL: Pactum reservatii dominii. Madrid 1925.

CASAS VALLÉS: «La reserva de dominio en la venta de inmuebles», RJC/1986, págs. 641 y ss.

COSSIO, F. DE: «La Ley de Ventas a Plazos», RCDI/1965 (XLI), págs. 1126 y ss. CRISTOBAL MONTÉS: La mora del deudor en los contratos bilaterales. Madrid 1984. DE CASTRO, F.: El negocio jurídico. Madrid 1963.

DÍEZ-PICAZO, L.: Fundamentos de Derecho Civil Patrimonial, T.II. Madrid 1986. DÍEZ-PICAZO Y GULLÓN: Sistema de Derecho Civil, T.II. Madrid 1983.

EGUSQUIZA BALMASEDA, M.A.: «Sobre el pacto de reserva de dominio (a propósito de la Sentencia de 19 de Mayo de 1989», RCDI/1991, págs. 9 y ss.

ESTRADA ALONSO, E.: «El crédito civil al consumo en la Ley 7/1995, de 23 de Marzo», CDC/1997, n 22.

JORDANO BAREA, J.: La categoría de los contratos reales. Barcelona 1958.

LALAGUNA DOMÍNGUEZ, E.: «Sobre la perfección de los contratos y el Código Civil», en Hom. a J. ROCA. Univ. de Murcia 1989, págs. 1071 y ss.

MARTÍN BERNAL, J.M.: «Notas apresuradas sobre la Ley 28/1998, de Venta a Plazos de Bienes Muebles», LA LEY/1998 (Septiembre).

MARTÍNEZ DE AGUIRRE Y ALDAZ, C.: Las ventas a plazos de bienes muebles. Madrid 1988. 
OERMANN: «La reserva de dominio en la compraventa (pactum reservati dominii)», RDP/1930.

POMPEYO CLARET: «El contrato de compraventa con reserva de dominio según la legislación y la jurisprudencia española», RDP/1930.

REVERTE NAVARRO, A.: Comentarios al Código Civil y Compilaciones Forales (Dir. ALBALADEJO), T.XVII, vol. $1^{\circ} \mathrm{A}$ (art. 1255), págs. 100 y ss.

RIVERA FERNÁNDEZ, M.: La posición del comprador en la venta a plazos con pacto de reserva de dominio. Valencia 1994.

ROCA GUILlAMÓN, J.: Comentarios al Código Civil y Compilaciones Forales (Dir. ALBALADEJO), T.XVII, vol. $1^{\circ}$ A (art. 1258). Edersa. Madrid 1993, págs. 420 y ss.

- «Los contratos de crédito al consumo. Forma y contenido, reembolso anticipado y cobros indebidos (Ley 7/1995, de 23 de Marzo)», en Crédito al Consumo... SANTOS BRIZ: Derecho de cosas. Madrid 1973.

SOTO NIETO: Derecho vivo. Jurisprudencia comentada, vol. II. Madrid 1971. TORRES LANA, J.A.: «Notas críticas a la Ley de Ventas a Plazos de Bienes Muebles», RDP/1975, págs. 604 y ss.

VÁZQUEZ RICHART, J.: «La compraventa a plazos (de los bienes muebles)». Madrid 1963.

ZUMALACÁRREGUI: «El Registro de reservas de dominio de bienes muebles vendidos a plazo», RCDI/1974, págs. 551 y ss. 